\title{
Endocrine regulation of fetal skeletal muscle growth: impact on future metabolic health
}

\section{Laura D Brown}

Department of Pediatrics (Neonatology), Perinatal Research Center, University of Colorado School of Medicine, Anschutz Medical Campus F441, 13243 East 23rd Avenue, Aurora, Colorado 80045, USA
Correspondence should be addressed to $L D$ Brown Email laura.brown@ucdenver.edu

\begin{abstract}
Establishing sufficient skeletal muscle mass is essential for lifelong metabolic health. The intrauterine environment is a major determinant of the muscle mass that is present during the life course of an individual, because muscle fiber number is set at the time of birth. Thus, a compromised intrauterine environment from maternal nutrient restriction or placental insufficiency that restricts muscle fiber number can have permanent effects on the amount of muscle an individual will live with. Reduced muscle mass due to fewer muscle fibers persists even after compensatory or 'catch-up' postnatal growth occurs. Furthermore, muscle hypertrophy can only partially compensate for this limitation in fiber number. Compelling associations link low birth weight and decreased muscle mass to future insulin resistance, which can drive the development of the metabolic syndrome and type 2 diabetes, and the risk of cardiovascular events later in life. There are gaps in knowledge about the origins of reduced muscle growth at the cellular level and how these patterns are set during fetal development. By understanding the nutrient and endocrine regulation of fetal skeletal muscle growth and development, we can direct research efforts toward improving muscle growth early in life to prevent the development of chronic metabolic diseases later in life.
\end{abstract}
Key Words
- muscle
- insulin
IGF1
- amino acids
- protein synthesis
- neonatal

Journal of Endocrinology (2014) 221, R13-R29

\section{Introduction}

Epidemiological studies have demonstrated that lower birth weight for a given gestational age increases an individual's risk of developing obesity (Valdez et al. 1994, Ravelli et al. 1999), coronary heart disease (Barker et al. 1993, 2010), glucose intolerance (Hales et al. 1991, Phipps et al. 1993, McKeigue et al. 1998), and type 2 diabetes (Curhan et al. 1996, Rich-Edwards et al. 1999) later in life. Small for gestational age (SGA) status at the time of birth, defined arbitrarily as birth weight $<10 \%$ on standard pediatric growth curves (Battaglia \& Lubchenco 1967), can result from many causes, one of which is placental insufficiency (Platz \& Newman 2008). Placental insufficiency is defined as a smaller-than-normal placenta, with or without specific transporter deficiencies, that restricts nutrient flow from the mother to the fetus and uniquely causes intrauterine growth restriction (IUGR; Molteni et al. 1978, Marconi et al. 2006, Marconi \& Paolini 2008, Regnault et al. 2013). Fetal IUGR leads to increased perinatal and neonatal morbidity and mortality (Pollack \& Divon 1992, Tuuli et al. 2011), as well as the later-life pathologies mentioned above. Although nearly every fetal organ system is affected in IUGR, skeletal muscle growth is particularly vulnerable because blood flow and nutrient supplies are preferentially shunted to vital organs in 
response to decreasing fetal oxygenation (Tchirikov et al. 1998, Yajnik 2004a). As a result, skeletal muscle growth is preferentially restricted (Yau \& Chang 1993, Padoan et al. 2004, Larciprete et al. 2005, Beltrand et al. 2008).

Skeletal muscle serves several important metabolic functions. First, resting energy expenditure varies considerably based on the amount of lean mass that an individual possesses (Mifflin et al. 1990, Nelson et al. 1992, Taguchi et al. 2011). Based on estimates for the energy required to maintain the muscle fractional protein synthetic rate (Waterlow 1984, Tipton et al. 2003), it has been proposed that greater muscle mass and increased energy expenditure from muscle protein turnover may contribute to the prevention of obesity (Newsholme 1978, Wolfe 2006). Second, skeletal muscle accounts for $80 \%$ of whole-body insulin-stimulated glucose uptake; thus, muscle maintains whole-body insulin sensitivity (DeFronzo et al. 1981). Third, several muscle secretory products or 'myokines' improve insulin sensitivity (Basaria $\&$ Bhasin 2012) and stimulate energy consumption within adipose tissue (Bostrom et al. 2012). Finally, sarcopenia, or the degenerative loss of skeletal muscle mass and function, affects $30 \%$ of adults over the age of 65 years and is a large contributor to morbidity and mortality (Doherty 2003). Thus, low muscle mass affects adult health and has important implications for quality of life, excess weight gain, and risk of developing insulin resistance and type 2 diabetes.

Reduced fetal skeletal muscle growth is not fully compensated after birth, as individuals who are born with low birth weight have lower muscle mass in adulthood (Gale et al. 2001, Kensara et al. 2005, Yliharsila et al. 2007). As skeletal myofiber number is set at the time of birth (Rowe \& Goldspink 1969, Wigmore \& Stickland 1983), it is possible that disruptions in myofiber formation during fetal life may not be fully recovered (Widdowson et al. 1972). In sheep models of maternal undernutrition or placental insufficiency, skeletal muscle growth is preferentially sacrificed and skeletal muscle mass is reduced at birth (Du et al. 2010). Under such circumstances, compensatory or 'catch-up' postnatal growth favors fat deposition and not muscle development (Louey et al. 2005, De Blasio et al. 2007, Ford et al. 2007). In humans, compelling associations link low birth weight and decreased muscle mass to future insulin resistance (Srikanthan \& Karlamangla 2011), development of the metabolic syndrome and type 2 diabetes (Barker et al. 2002, Whincup et al. 2008, Atlantis et al. 2009), and risk of cardiovascular events later in life (Basaria \& Bhasin 2012). Thus, suppressed development of muscle in IUGR fetuses could be a major contributor to their increased risk of later-life sarcopenia, obesity, and diabetes.

An understanding of how fetal skeletal muscle growth adapts to nutrient availability is important for determining how deficits in muscle growth contribute to metabolic diseases in adulthood. Therefore, the objectives of this article are to i) review the fundamentals of fetal myogenesis; ii) review the experimental studies showing that fetal undernutrition from maternal dietary restriction or placental insufficiency influences skeletal muscle growth; iii) highlight the epidemiological studies showing that low birth weight is associated with reduced muscle mass in adulthood; and iv) discuss how insufficient muscle mass as a result of IUGR might influence long-term metabolic health. Finally, potential therapeutic approaches to improving muscle mass in IUGR fetuses and research needs in this area are addressed.

\section{Skeletal muscle development}

\section{Proliferation and differentiation of myoblasts and myofibers}

Myoblasts are mononuclear cells that have the capacity to proliferate and differentiate into skeletal myofibers (Gerrard \& Grant 2003, Zammit et al. 2006). Myoblasts, as well as adipocytes and fibroblasts, differentiate from the multipotent mesenchymal stem cell (MSC) population in the developing human embryo (Pittenger et al. 1999). Because both myocytes and adipocytes share a common progenitor, the milieu of nutrients and growth factors in early embryonic and fetal life could affect MSC commitment to either a myogenic or an adipogenic lineage (Du et al. 2013). Indeed, exposure of C2C12 myoblasts to adipogenic inducers in vitro has been shown to convert the differentiation pathway of myoblasts into that of adipoblasts (Teboul et al. 1995).

Once differentiated, myoblasts are classified as embryonic, fetal, or adult (Gerrard \& Grant 2003). Embryonic myoblasts fuse to form primary myofibers by $20 \%$ of the length of gestation in sheep (Russell \& Oteruelo 1981). Primary myofibers provide the scaffolding for the proliferation and differentiation of fetal myoblasts into secondary myofibers (Beermann et al. 1978). Secondary myofibers comprise the majority of myofibers and are highly nutrient responsive (Ward \& Stickland 1991, Dwyer et al. 1994, Zhu et al. 2004). Secondary myogenesis occurs between 20 and $70 \%$ of the length of gestation (Russell \& Oteruelo 1981) and involves the proliferation of fetal myoblasts followed by the expression of muscle regulatory

Published by Bioscientifica Ltd. 
factors (MRFs) (Fig. 1a and b). MRFs are a set of helix-loophelix transcription factors, including MYF5, MYOD (MYOD1), MRF4 (MYF6), and myogenin, that are expressed in a sequential manner during the differentiation process (Berkes \& Tapscott 2005, Braun \& Gautel 2011). Targets of the MRFs include proteins that regulate the switch from proliferation to differentiation, including retinoblastoma protein (RB (RB1)), which is an inhibitor of cell-cycle progression. Cyclin D1 and cyclin-dependent kinase 4 (CDK4) phosphorylate and inhibit RB to induce proliferation (Weinberg 1995, Spiller et al. 2002). As differentiation occurs, $M Y O D$ binds to myostatin, which results in the withdrawal of myoblasts from the cell cycle (Spiller et al. 2002). In addition, P21 inhibits CDK4 so that $\mathrm{RB}$ remains dephosphorylated to reduce cell-cycle activity (Guo et al. 1995). Cell-cycle withdrawal is concomitant with the expression of MYOD, MYF5, and myogenin (Sabourin \& Rudnicki 2000; Fig. 1c).

Myogenesis is nearly complete by the end of gestation, as a full complement of myofibers has been observed at the time of birth in both mice and piglets (Rowe \& Goldspink 1969, Wigmore \& Stickland 1983). Postnatal muscle growth occurs primarily by myofiber hypertrophy, as has been demonstrated in mice (White et al. 2010). Muscle satellite cells (or adult myoblasts) reside between the basal lamina and myofiber membrane (Yin et al. 2013). During late fetal and early postnatal life, myofiber growth is accompanied by the proliferation and fusion of satellite cells with existing myofibers (Moss \& Leblond 1971, White et al. 2010). During later stages of postnatal life and into adult life, increases in myofiber cross-sectional area occur without significant changes in myonuclear number (White et al. 2010). In response to extreme mechanical loading, injury, inflammation, and/or anabolic hormone stimulation, satellite cells serve as bona fide stem cells that can proliferate and differentiate to create new muscle (Ten Broek et al. 2010, Yin et al. 2013). Thus, satellite cells retain plasticity and regenerative capacity during postnatal life. However, the postnatal satellite cell population is vulnerable to fetal undernutrition. When pregnant mice were undernourished during the last week of gestation, pups at 7 weeks of postnatal age had reduced muscle mass, a 33\% decrease in skeletal muscle precursor cells, and reduced regenerative capacity in response to muscle injury in vivo

(a)

(b)

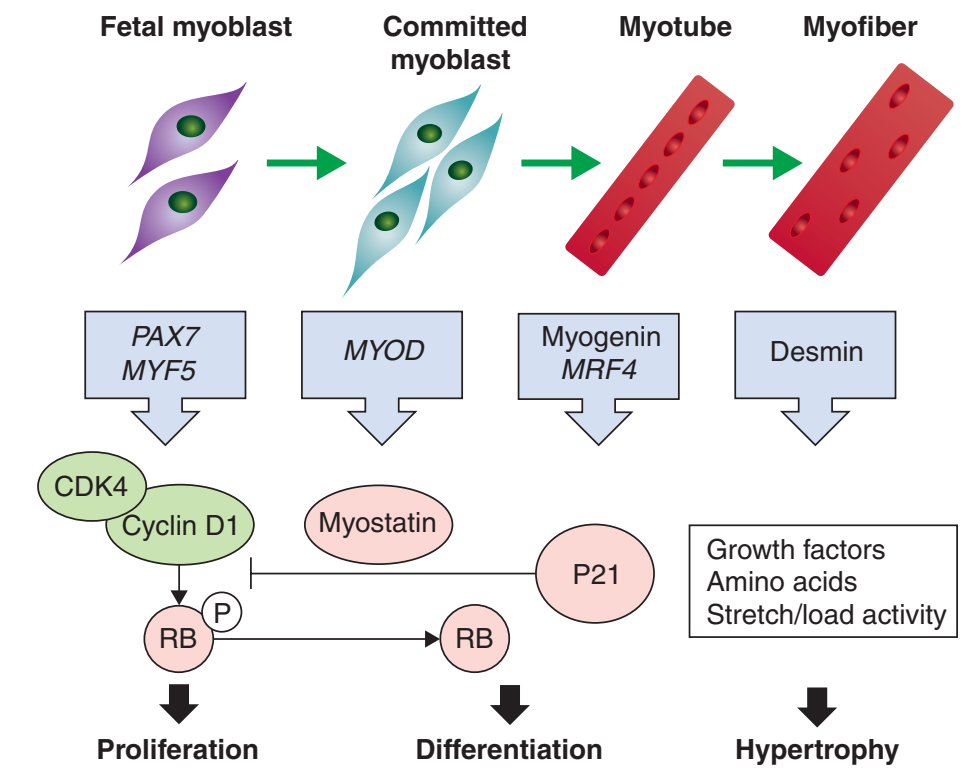

\section{Figure 1}

Key regulatory genes and proteins involved in fetal myogenesis. (a) Schematic diagram showing the differentiation of proliferating myoblasts into multinucleated myotubes and maturation into myofibers during fetal life. (b) Expression of muscle regulatory factors (MRFs) during myogenesis: PAX7 and MYF5 are expressed in the myoblast. The progression of differentiation is marked by the temporal expression of MYOD, MRF4, and myogenin. Desmin is the major intermediate filament expressed in mature muscle and its expression increases during gestation. (c) Targets of MRFs regulate the switch from proliferation to differentiation: expression of cyclin D1 and CDK4 induces myoblast proliferation by maintaining the inhibitor retinoblastoma protein (RB) in its phosphorylated and inactive state. As differentiation is activated, MYOD binds to myostatin and myoblasts withdraw from the cell cycle. In addition, P21 inhibits CDK4, which results in the dephosphorylation of RB to reduce cell cycle activity. This process results in the withdrawal of myoblasts from the cell cycle and subsequent fusion into myotubes. Myotube maturation and hypertrophy are stimulated by growth factors, amino acids, and stretch/load activity (Molkentin \& Olson 1996, Yang \& Makita 1996, Gaster et al. 2001, Zammit et al. 2006). http://joe.endocrinology-journals.org DOI: $10.1530 / J O E-13-0567$
(C) 2014 Society for Endocrinology Printed in Great Britain
Published by Bioscientifica Ltd 
(Woo et al. 2011). Whether the satellite cell population is permanently compromised during pregnancies complicated by IUGR in humans is an important question when considering the long-term effects of the compromised intrauterine environment.

\section{Myofiber hypertrophy}

Myofiber hypertrophy, or an increase in fiber diameter and length with or without satellite cell fusion, occurs as a net increase in balance between protein synthesis and degradation. When the rate of protein synthesis exceeds that of protein breakdown, the end result is net protein accretion and myofiber hypertrophy. Nutrients and growth factors are primary regulators of net protein balance and myofiber hypertrophy. However, stretching and loading of muscle also regulate muscle mass and protein synthesis, even during fetal life (Racca et al. 2013).

Nutrients and growth factors coordinate net protein accretion in skeletal muscle through the mammalian target of rapamycin (mTOR). Two multiunit complexes constitute mTOR: mTORC1 and mTORC2. The mTORC1 complex senses both intracellular and extracellular cues, such as growth factors, amino acids, energy status, and oxygen availability to either stimulate or inhibit cell growth. Comprehensive reviews of mTOR signaling and its coordination with cell growth in skeletal muscle are available (Goodman et al. 2011, Dodd \& Tee 2012, Laplante \& Sabatini 2012, Weigl 2012).

Under conditions of nutrient sufficiency (Fig. 2), growth factors such as insulin and insulin-like growth factor 1 (IGF1) bind to their respective tyrosine kinase receptors, which phosphorylate insulin receptor substrate 1 (IRS1). IRS1 activates phosphoinositide 3-kinase and protein kinase B (AKT) to stimulate mTORC1 (Takahashi et al. 2002). Amino acids such as leucine can stimulate mTORC1 independently of insulin or IGF1 by binding to leucyl-tRNA synthetase and activating RAG GTPase proteins, thus bringing Ras homolog enriched in brain (RHEB) to the surface of the lysosome (Han et al. 2012). Based on these positive inputs, mTORC1 then activates two major downstream effectors, ribosomal protein S6 kinase and 4E-binding protein 1 (4EBP1). mTORC1 phosphorylates the translation initiation repressor 4EBP1, which then releases eukaryotic initiation factor $4 \mathrm{E}$ and enables it to form the translation initiation complex.

Under conditions of nutrient and energy restriction (Fig. 2), rates of protein synthesis are decreased by the activation of the tuberous sclerosis complex (TSC) and suppression of mTORC1 activity. Limited oxygen and energy availability to the cell are sensed by three key proteins, all of which can activate TSC: hypoxia-inducible factor (HIF), regulated in development and DNA damage responses 1 (REDD1 (DDIT4)), and 5'-AMP-activated protein kinase (AMPK) (Hardie et al. 2012, Liu et al. 2012). AMPK, which is activated by an increased AMP:ATP ratio, also inhibits eukaryotic elongation factor 2 and peptide chain elongation (Leprivier et al. 2013). When amino acids are not available, uncharged tRNAs activate the protein general control nonrepressed 2 to phosphorylate eIF2A and suppress mRNA translation (Dong et al. 2000, Saad et al. 2013).

In catabolic states such as starvation, cancer, and burn injury, proteolytic pathways are activated in skeletal muscle for the purpose of supplying amino acids to organs such as the heart, liver, and brain (Biolo et al. 1995, Kadar et al. 2000, Biolo et al. 2002). Two proteolytic systems are active within skeletal muscle: ubiquitin-proteasome pathway (mediated by ubiquitin ligases atrogin 1 and muscle RING-finger protein 1 (MURF1 (TRIM63))) and the autophagy-lysosome pathway. These pathways can modulate one another and are under coordinated control with protein synthetic pathways to maintain proper cell size (Bonaldo \& Sandri 2013). AKT and forkhead box transcription factors $(F O X O)$ play a crucial role in the regulation of this process (Fig. 2). The translocation of FOXO into the nucleus in its dephosphorylated state is required for the upregulation of atrogin 1 and MURF1, as well as for the transcription of autophagy-related genes, including LC3 (MAP1LC3A) and BNIP3 (Mammucari et al. 2007, Zhao et al. 2007). With growth factor stimulation, AKT phosphorylates $F O X O$, promoting its export from the nucleus, which thereby suppresses proteolysis when conditions favor protein synthesis. A recent report has also shown that autophagy in skeletal muscle of starved rats is regulated by insulin via mTORC1-mediated inhibition of UNC 51 like kinase (ULK1; Naito et al. 2013).

Our laboratory and others have shown that the AKTmTORC1 signaling pathway is active in the skeletal muscle of fetal sheep in response to a variety of anabolic stimuli such as amino acids, insulin, and IGF1 (Shen et al. 2002, Anderson et al. 2005, Brown et al. 2009). However, it is not known whether the human IUGR fetus slows protein synthetic rates in muscle via adaptation to reduced levels of nutrients and growth factors or whether it activates protein breakdown as a result of cellular stress. Probably, these processes are not mutually exclusive; the fetus might develop a slower growth rate in response to decreased nutrient supply early in the course of placental

Published by Bioscientifica Ltd. 


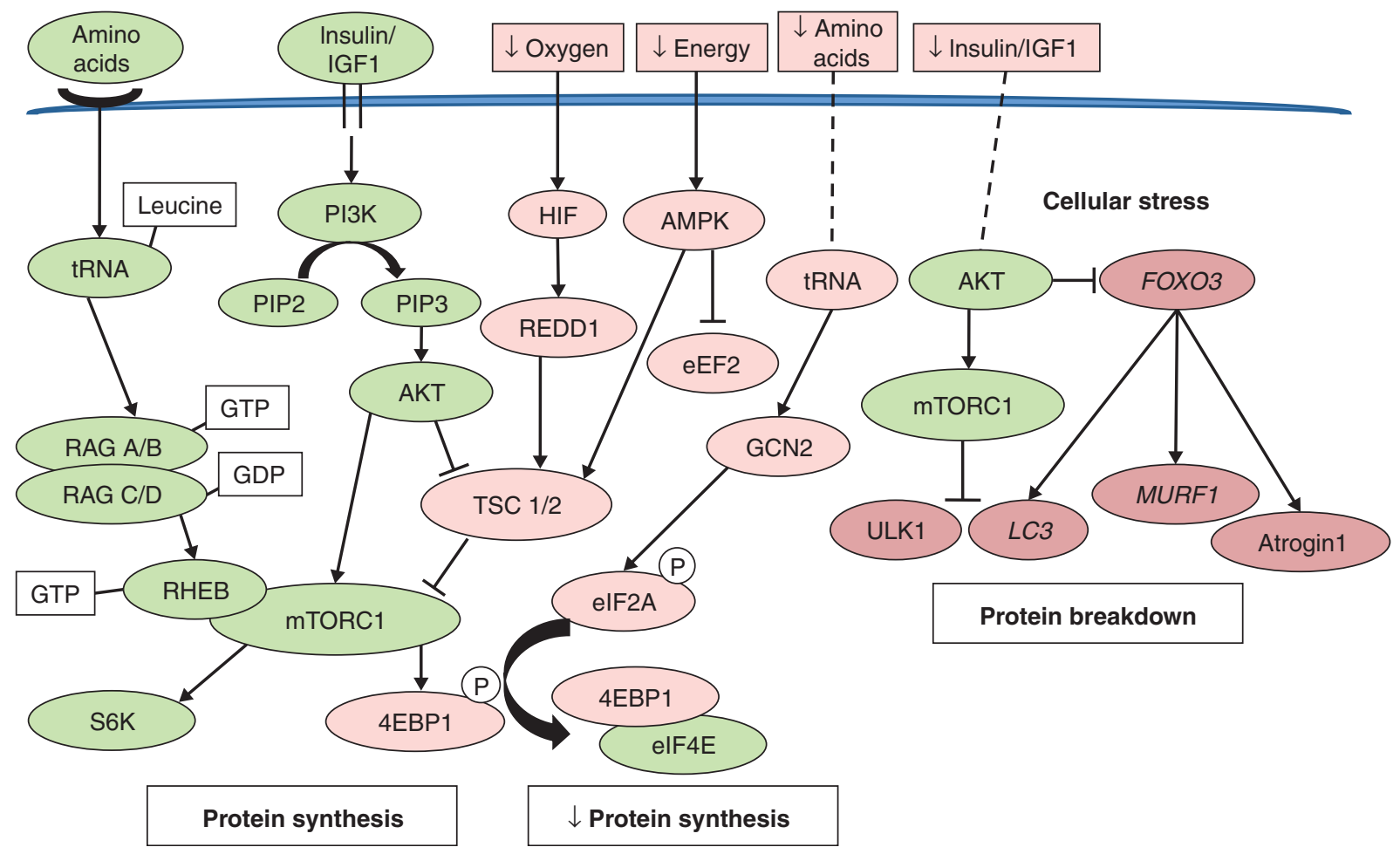

Figure 2

Major signaling pathways that regulate myofiber growth. Under conditions of nutrient sufficiency (depicted in green), nutrients (leucine), and growth factors (insulin and IGF1) coordinate net protein accretion in skeletal muscle through the mammalian target of rapamycin complex 1 (mTORC1). Leucine binds to its respective leucyl-tRNA synthetase and activates RAG GTPase proteins, thus bringing Ras homolog enriched in brain (RHEB) to the surface of the lysosome. Insulin and IGF1 bind to their respective tyrosine kinase receptors, which phosphorylate insulin receptor substrate 1 (IRS1). IRS1 activates phosphoinositide 3-kinase (PI3K) and protein kinase $B(A K T)$ to stimulate mTORC1. mTORC1 activates ribosomal protein $\mathrm{S} 6$ kinase (S6K) and phosphorylates the translation initiation repressor 4EBP1, which then releases eukaryotic initiation factor 4E (eIF4E)

insufficiency, but then might activate catabolic pathways in the setting of worsening hypoxia and increased catecholamine and cortisol production as nutrient restriction progresses. This is a fundamental area of future investigation, as treatments to improve muscle growth will vary based on whether growth is slowed because of decreased anabolism or increased catabolism.

\section{Nutrient and growth factor regulation of fetal skeletal muscle growth Growth factors}

Skeletal muscle growth is regulated by several growth factors, including IGF1, insulin, basic fibroblast growth and enables it to form the translation initiation complex. Under conditions of oxygen and energy restriction (depicted in pink), hypoxia-inducible factor (HIF), regulated in development and DNA damage responses 1 (REDD1), and $5^{\prime}$-AMP-activated protein kinase (AMPK) decrease the rates of protein synthesis by activating tuberous sclerosis complex (TSC) to suppress mTORC1 activity. When amino acids are not available, uncharged tRNAs activate the protein general control nonrepressed $2(\mathrm{GCN} 2)$ to phosphorylate eIF2A and suppress mRNA translation. Under conditions of cellular stress (depicted in red), forkhead box transcription factor 3 (FOXO3) in its dephosphorylated state is translocated into the nucleus to upregulate ubiquitin-mediated proteolysis markers atrogin 1 and MURF1, as well as the autophagy marker $L C 3$. Dashed lines represent lack of signal.

factor (bFGF), and transforming growth factor- $\beta$ (TGFB) (Allen \& Rankin 1990, Frost \& Lang 2012).

Several studies in humans, transgenic animals, and cell lines have demonstrated that IGF1 regulates both myoblast proliferation and myofiber hypertrophy. Igf1 heterozygous knockouts in mice have reduced muscle mass (Powell-Braxton et al. 1993), whereas homozygous knockouts have severe muscle hypoplasia due to both decreased myocyte number and myofiber cross-sectional area (Liu et al. 1993, Mavalli et al. 2010). Similarly, mutations in the IGF1 and IGF1R genes in humans cause both IUGR and postnatal growth restriction (Woods et al. 1996, Abuzzahab et al. 2003). Conversely, excessive IGF1 results in increased muscle mass and hypertrophy in postnatal life, as demonstrated by

Published by Bioscientifica Ltd. 
overexpressing Igf1 in a transgenic mouse or by direct i.v. infusion into rats (Coleman et al. 1995, Adams \& McCue 1998). In subconfluent myoblasts in vitro, IGF1 acts initially to promote proliferation (Rosenthal \& Cheng 1995). In differentiated myotubes, IGFI promotes protein synthesis (Harper et al. 1987, Coleman et al. 1995).

Insulin also functions as a potent fetal skeletal muscle growth factor. Pancreatectomy in fetal sheep results in growth-restricted fetuses with decreased upper and lower extremity limb length (Fowden et al. 1989). These experiments confirm lack of insulin as the cause of growth restriction in cases of pancreatic agenesis in humans (Lemons et al. 1979). Conversely, studies in catheterized fetal sheep have shown that both insulin and IGF1 infusions promote whole-body and musclespecific protein synthesis (Milley 1994, Boyle et al. 1998, Shen et al. 2003). Furthermore, insulin infusion into neonatal piglets stimulates skeletal muscle protein synthesis (Davis et al. 2002). High doses of insulin (at least $0.1 \mu \mathrm{M}$ ) increase protein synthesis and suppress protein breakdown in both primary cultured and immortalized myotubes in vitro (Gulve \& Dice 1989, Cassar-Malek et al. 1999, Shen et al. 2005), including myotubes harvested and cultured directly from fetal sheep (Harper et al. 1987).

Other growth factors, including bFGF and TGFB, upregulate cyclin D1 levels in myoblasts, which then stimulate proliferation and myogenesis (Rao \& Kohtz 1995). Myostatin is a member of the TGFB family of regulators and a potent inhibitor of myogenesis. Doublemuscled cattle carry an inactivating mutation in the myostatin gene and have $20 \%$ more muscle than normal-muscled cattle (Grobet et al. 1997). Myostatinnull mice have two to three times greater muscle mass than WTs (McPherron et al. 1997). These animals also exhibit less insulin resistance and fat deposition, demonstrating the important role of muscle in the regulation of adipose tissue balance and insulin sensitivity (Guo et al. 2012). Follistatin is an inhibitor of myostatin and works through the activation of the IGF1R. Mice overexpressing follistatin have a threefold greater increase in myofiber diameter than those overexpressing follistatin with a nonfunctional IGF1R (Kalista et al. 2012).

\section{Amino acids}

Amino acids are essential for muscle protein synthesis. In addition to forming the building blocks of proteins, amino acids have important regulatory effects on mTORC1 activation and muscle protein synthesis. Amino acids increase skeletal muscle protein synthesis in adults, both under normal postprandial conditions and during catabolic states such as after trauma and sepsis (Wolfe 2005, Drummond \& Rasmussen 2008). Increasing amino acid delivery positively affects net protein balance in infants born preterm or at term (Poindexter et al. 1997, Thureen et al. 2003, Reynolds et al. 2008). In neonatal piglets, mixed amino acid or leucine supplementation increases muscle protein synthesis through mTORC1-dependent pathways (O'Connor et al. 2003a,b, Suryawan et al. 2008, 2012).

Studies that address the effects of amino acids on skeletal muscle growth during fetal life are more limited. One study carried out by de Boo et al. (2005) showed that a mixed amino acid infusion administered for $4 \mathrm{~h}$ increased whole fetal protein accretion in fetal sheep studied during late gestation. Our laboratory showed that a mixed amino acid infusion activated signaling through mTORC1 within the skeletal muscle of fetal sheep, but only when there was a concurrent rise in insulin concentrations (Brown et al. 2009). Further studies to determine the interactive roles of amino acids and growth factors in the regulation of fetal skeletal muscle development are needed.

\section{Reduced fetal skeletal muscle growth: insights from models of fetal undernutrition}

\section{Effects of fetal undernutrition on myoblast proliferation and myofiber number}

Studies in mice and pigs have shown that myofiber number is set around the time of birth (Rowe \& Goldspink 1969, White et al. 2010). Similar growth patterns have been observed in humans, as DNA content in the gastrocnemius muscle increases exponentially between weeks 15 and 25 of gestation and plateaus by term (Widdowson et al. 1972). Thus, conditions that deprive the fetus of nutrients and growth factors during myofiber formation can have a lasting impact on myofiber number.

Studies of maternal nutrient restriction during pregnancy in a variety of animal models have shown dramatic effects of reduced nutrient supply on the establishment of fetal myofiber number, with secondary myofibers being more vulnerable to restricted fetal nutrient supply than primary myofibers in sheep and pigs (Ward \& Stickland 1991, Dwyer et al. 1994, Zhu et al. 2004). In rats fed 30\% of an ad libitum diet during gestation, secondary myofiber number within the fetal soleus and lumbrical muscles was decreased by 30\% (Wilson et al. 1988). When pregnant

Published by Bioscientifica Ltd 
sheep were diet restricted by $50 \%$ during early gestation and mid-gestation, which are coincident with the maximal period of myoblast proliferation (Fahey et al. $2005 a$ ), fetal myofiber number was decreased at midgestation and this effect persisted when tested at 8 months of age (Zhu et al. 2004, 2006). Guinea piglets born to mothers who had a $40 \%$ reduction in feed intake during the entirety of gestation had $25 \%$ less myofibers within glycolytic muscle types (Dwyer \& Stickland 1992a). Similar reductions in myofiber number were observed when the duration of maternal dietary restriction in guinea pigs was shortened, but still overlapped with the peak period of secondary myofiber formation (Dwyer et al. 1995). Runted piglets, or those piglets that weigh $60 \%$ of the mean litter weight, have persistent deficits in myofiber number and muscle mass as adults (Powell \& Aberle 1980). They also become fatter and less insulin sensitive (Poore \& Fowden 2004). Myofiber number in pigs positively correlated with average daily weight into early adulthood (70-130 days of postnatal age), providing evidence that myofiber number influences postnatal muscle growth trajectory (Dwyer et al. 1993).

The mechanisms for restriction of muscle fiber number from fetal undernutrition are not understood, though there is evidence for the suppression of fetal myoblast cellcycle activity. In a model of placental insufficiency resulting from sheep bred to produce litters of multiple lambs of variable birth weight (from 2 to $5 \mathrm{~kg}$ ), low-birthweight lambs had less muscle DNA and decreased percentage of nuclei entering the S-phase of the cell cycle, indicative of fewer myonuclei per myofiber and decreased cell-cycle activity compared with larger lambs (Greenwood et al. 1999, 2000). This is not unexpected, given that maternal nutrient restriction results in reductions in circulating fetal plasma IGF1 concentrations in rats (Straus et al. 1991), guinea pigs (Dwyer \& Stickland 1992b), and sheep (Lee et al. 1997, Osgerby et al. 2002, Costello et al. 2008, Ward et al. 2008). However, it should be noted that total myofiber number was not different between small and large lambs in this study (Greenwood et al. 1999). There remain many unanswered questions about the interaction between the effects of chronic nutrient restriction and subsequent decreases in fetal growth factor concentrations on myoblast proliferation and the capacity for compensatory muscle growth.

\section{Effects of fetal undernutrition on myofiber hypertrophy}

Studies that extend maternal dietary restriction into late gestation to evaluate the effects on fetal myofiber hypertrophy are more limited. When pregnant sheep were fed $70 \%$ of a control diet beginning at day 26 of gestation, the fetal semitendinosus muscle weight was decreased by $20 \%$ on day 135 of gestation (Osgerby et al. 2002). When pregnant sheep were diet restricted by $50 \%$ during mid-gestation to late gestation (days 85-115 of a 145-day gestation period), individual muscle weights of offspring at 2 weeks of life were decreased by 15-20\% compared with controls (Fahey et al. 2005b). A shorter but more severe dietary restriction allowing 30\% of ad libitum intakes for 7 days during late gestation in sheep resulted in decreased muscle weights compared with controls (Greenwood et al. 1999). In a model of placental insufficiency in sheep bred to produce multiple lambs per litter, the trajectory of muscle growth was decreased in small, runted lambs compared with large lambs, as measured by weight over time between 85 and 130 days of gestation. The muscle protein:DNA ratio on day 130 of gestation in small lambs was also decreased (Greenwood et al. 1999).

Normalizing dietary intake after early maternal nutrient restriction (days 30-70) in pregnant sheep, however, resulted in compensatory myofiber hypertrophy as evidenced by fewer myofibers but larger fiber crosssectional area compared with controls (Fahey et al. 2005b, Zhu et al. 2006). The phenomenon of postnatal catch-up growth after fetal growth restriction has been well described in a variety of species, including in humans (Jimenez-Chillaron \& Patti 2007, Tudehope et al. 2013). However, the extent to which muscle growth is able to fully compensate during postnatal life after nutrient restriction in utero is not entirely clear. Longer-term follow-up of sheep into adolescence and adulthood after mid-gestation nutrient restriction has shown accelerated fat deposition at the expense of lean mass growth (Louey et al. 2005, De Blasio et al. 2007, Ford et al. 2007). In undernourished fetal rats, compensatory myofiber hypertrophy in the diaphragm occurs through postnatal day 21, though adult myofiber cross-sectional area is ultimately smaller (Prakash et al. 1993). These results, taken together, indicate decreased protein accretion and fetal myofiber hypertrophy as a result of fetal undernutrition, with partial, but not complete capacity for compensatory muscle growth during postnatal life.

\section{Effects of fetal undernutrition on myofiber maturation}

A complex schema exists for defining muscle fiber types in mammals based on a variety of features, including the predominant type of myosin heavy chain (MHC)

Published by Bioscientifica Ltd 
expressed (type I, type IIa, type IIx, and type IIb), contractile machinery and speed of contraction, distribution of oxidative and glycolytic enzymes, and mitochondrial density (Pette \& Staron 2001, Schiaffino \& Reggiani 2011). Fiber type composition of skeletal muscle can undergo changes based on environmental influences (Simoneau \& Bouchard 1995), as myofibers can be affected by neuromuscular activity, exercise training, mechanical loading, and aging (Pette \& Staron 2001). Additionally, maternal dietary restriction results in fiber type transitions in offspring, generally favoring increased type I fiber expression. For example, studies that have evaluated fiber type shifts in the late fetal or early neonatal period after maternal dietary restriction in both sheep and rats found either a relative increase in type I oxidative fibers or a relative decrease in glycolytic type II fibers (Fahey et al. 2005b, Prakash et al. 1993, Costello et al. 2008). Runted piglets have more type I fibers than their appropriately grown littermates (Wank et al. 2000, Bauer et al. 2006). These findings are not uniformly consistent, as pups of undernourished pregnant mice exhibited a shift from type I to type IIa and IIb fibers at 7 weeks of age (Woo et al. 2011). However, any adaptation in MHC expression that develops in response to fetal undernutrition does not appear to persist and, in fact, may shift during the lifespan. For example, when fiber type assessments were extended into the adolescent period in offspring of nutrientrestricted sheep, glycolytic type II fibers predominated (Zhu et al. 2006, Daniel et al. 2007). Low-birth-weight humans evaluated at 19 years of age had a decreased proportion of type IIa fibers compared with a control group with normal birth weights (Jensen et al. 2007). Further work in this area is required to determine the longterm significance of fiber type shifts as a result of fetal undernutrition.

\section{Skeletal muscle growth is particularly vulnerable in the fetus exposed to fetal undernutrition from placental insufficiency}

Placental insufficiency is a condition whereby a poorly functioning placenta restricts nutrient supply to the fetus, preventing normal fetal growth (Figueras \& Gardosi 2011). If placental insufficiency begins early in pregnancy, the entire process of myogenesis is at a high risk of getting attenuated and/or disrupted. Deficient skeletal muscle mass is a characteristic of the human fetus affected by IUGR (Yau \& Chang 1993, Padoan et al. 2004, Larciprete et al. 2005, Beltrand et al. 2008). Placental insufficiency commonly begins early in pregnancy so that nutrient restriction to the fetus is chronic, progressive, and severe, often leading to preterm delivery when fetal well-being is severely compromised (De Jesus et al. 2013). Fetal skeletal muscle growth is particularly vulnerable during placental insufficiency, because blood, oxygen, and nutrients are preferentially shunted to vital organs (Tchirikov et al. 1998, Yajnik 2004a). Consequently, at least in animal models of placental insufficiency, skeletal muscle weight is disproportionately reduced compared with body weight (Desai et al. 1996, Greenwood et al. 2000, Bauer et al. 2003).

Placental size and function, fetal growth, and fetal nutrient and growth factor availability have been well characterized in a sheep model of chronic and progressive placental insufficiency, which was developed to mimic a natural condition of placental and fetal growth restriction that occurs in sheep that carry their pregnancies in the hot summer months (PI-IUGR; Bell et al. 1987; Fig. 3). The PI-IUGR model accurately reflects the characteristics that occur during human pregnancies affected by conditions that cause placental insufficiency and IUGR (Barry et al. 2008). Similar to maternal dietary restriction during pregnancy, fetal plasma insulin and IGF1 concentrations in PI-IUGR fetuses are $50 \%$ of the normal values as early as $70 \%$ of the total length of pregnancy (Fig. 3; de Vrijer et al. 2006, Thorn et al. 2009, Macko et al. 2013). Other sheep models of chronic placental insufficiency caused by prepregnancy reduction of placental attachment sites or uteroplacental embolization also demonstrate decreased fetal insulin and IGF1 concentrations (Owens et al. 1994, Eremia et al. 2007), as do human IUGR fetuses (Nicolini et al. 1990, Lassarre et al. 1991, Leger et al. 1996, Iniguez et al. 2006). Leucine flux from the mother to the fetus is decreased by $90 \%$ of the length of gestation in PI-IUGR sheep (Fig. 3; Brown et al. 2012, Regnault et al. 2013). Similarly, amino acid transport across the placenta is impaired in the third trimester of human IUGR pregnancies (Cetin et al. 1992, Paolini et al. 2001).

Two of the distinguishing features that separate models of placental insufficiency from maternal dietary restriction are fetal hypoxemia and increased production of counter-regulatory hormones. In the PI-IUGR sheep model, norepinephrine and cortisol concentrations are increased (Leos et al. 2010), and fetuses are severely hypoxemic (Regnault et al. 2007, Leos et al. 2010), consistent with evidence from severe IUGR in human pregnancies (Pardi et al. 1993). Oxygen sensors such as HIF (HIF1A) and AMPK (PRKAA1) might play a role in the regulation of fetal muscle growth under conditions of placental insufficiency, as has been shown in placentas

Published by Bioscientifica Ltd. 


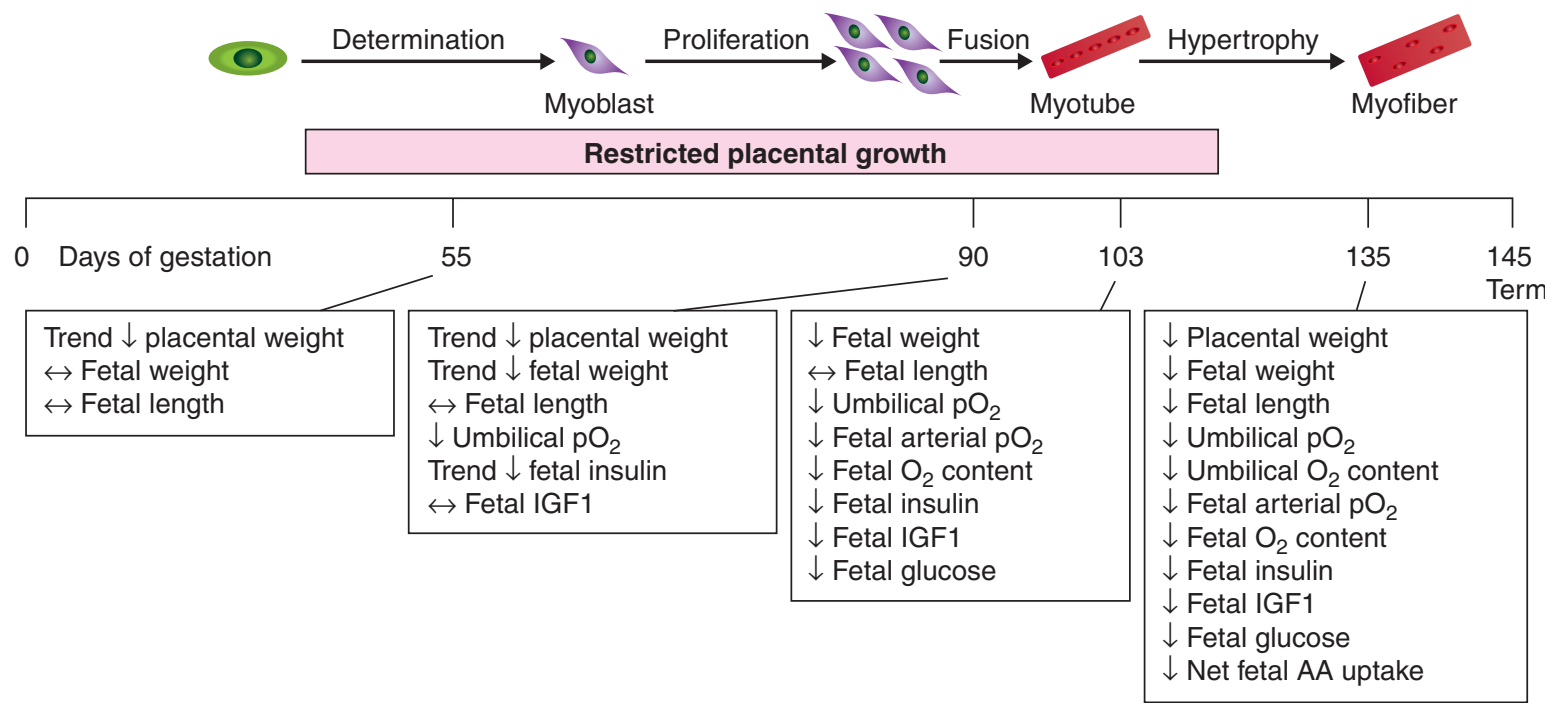

\section{Figure 3}

Progressive physiological changes in a model of placental insufficiencyinduced IUGR (PI-IUGR) in relation to fetal myogenesis. Pregnant sheep were housed in an environmental chamber with elevated ambient temperatures to restrict placental growth (PI-IUGR) beginning on day 40 for a maximum of 80 days during their 145 -day gestation period. Placental weights, fetal weights, and fetal lengths were compared between PI-IUGR sheep and sheep housed in thermo-neutral conditions (controls) during early gestation (day 55), mid-gestation (days 90 and 103), and late gestation (day 135). At mid- and late-gestation time points, surgery was performed in PI-IUGR and control sheep for the placement of fetal

collected from human IUGR pregnancies (CindrovaDavies et al. 2013).

\section{Relationships between low birth weight and skeletal muscle mass in humans}

Epidemiological evidence supports that reduced muscle mass in adulthood is, in part, due to environmental influences from placental insufficiency during fetal life. Such evidence has been generated by studies carried out in infants with a birth weight $<2500 \mathrm{~g}$ at term gestation or who were documented as SGA. Two important studies using epidemiological data from the third National Health and Nutrition Examination Survey (NHANES) cohort have identified low birth weight as an early predictor of reduced muscle growth in childhood. Hediger et al. (1998) first demonstrated an overall deficit in the amount of muscularity estimated by anthropometric measurements of upper-arm circumference in SGA infants compared with appropriately sized for gestational age (AGA) infants up to 3 years of age. Baker et al. (2010) further showed that while head circumference growth is maintained between 2 months and 8 years of age in SGA children compared umbilical and arterial sampling catheters to compare umbilical and feta oxygenation, circulating fetal growth factor concentrations, and fetal glucose and amino acid (AA) concentrations. Arrows $(\downarrow)$ represent changes in parameters in PI-IUGR animals compared with controls; $\leftrightarrow$, no change in PI-IUGR animals and controls. A schematic showing the progression of fetal myogenesis during ovine gestation is shown at the top of the figure (Fahey et al. 2005a, Regnault et al. 1999, 2002, 2007, Limesand et al. 2006, de Vrijer et al. 2006, Ziebell et al. 2007, Arroyo et al. 2008, 2009, Thorn et al. 2009, Brown et al. 2012, Macko et al. 2013).

with AGA children, muscle growth remains stunted. When body composition was measured by dual-energy X-ray absorptiometry (DXA) in adolescents, low birth weight was found to be associated with decreased lean body mass independent of age, sex, pubertal stage, physical activity, and height (Singhal et al. 2003). Even as early as the immediate neonatal period, lean body mass was found to increase between 36 and 41 weeks in AGA neonates, but not in SGA neonates (Lapillonne et al. 1997).

The association between birth weight and muscle mass extends into adulthood. Several large populationbased studies have found that low birth weight predicts lower adult muscle mass (measured by DXA) in men and women during young adulthood (Kahn et al. 2000), middle-ages (Sayer et al. 2004, Kensara et al. 2005, Yliharsila et al. 2007), and late adulthood (Gale et al. 2001). Monozygotic twin studies in both men and women have found that the lower-birth-weight twin had less lean body mass and more subcutaneous fat than the heavier twin, supporting the consistent observation that the intrauterine environment, independent of genetic influences, predicts lean mass in adulthood (Loos et al. 2001, 2002). Even as late as the seventh decade of life, $25 \%$ of the

Published by Bioscientifica Ltd. 
variation in lean body mass was explained by birth weight (Gale et al. 2001). As obesity is generally associated with excess lean as well as fat mass, obesity found following low birth weight presents a unique mechanism that may not necessarily be due to increased energy intake that characterizes most cases of adult obesity.

\section{Effects of IUGR on skeletal muscle growth and function and long-term metabolic health}

Populations around the world are faced with epidemic increases in the incidence of obesity and diabetes. In the USA, more than one-third of adults and $17 \%$ of children and adolescents are obese (Ogden et al. 2012). Projections show that one in three Americans will develop diabetes by 2050 (Boyle et al. 2010). Compelling associations link low birth weight and decreased muscle mass to the development of the metabolic syndrome and type 2 diabetes (Whincup et al. 2008, Atlantis et al. 2009) and an increased risk of cardiovascular events later in life (Basaria \& Bhasin 2012). Thus, it is imperative that all major factors that contribute to diabetes and obesity risk be investigated, including the role of disproportionately reduced muscle mass.

The amount of muscle mass has major impact on fat deposition, insulin sensitivity, strength, and locomotion. Interactions between muscle mass, fat mass, and fat distribution (visceral vs subcutaneous) have been demonstrated, supporting the concept that reduced capacity for muscle growth favors and accelerates visceral fat deposition and obesity (Yajnik 2004b, Kensara et al. 2005). For example, intrauterine growth patterns contribute to the 'thin-fat' phenotype of Indian diabetic patients. This phenotype is characterized by less muscle mass but greater body fat and central obesity (Yajnik 2004b). Infants born in India compared with infants born in the UK are lighter, shorter, and thinner, but have similar subscapular skin fold thicknesses, indicating smaller muscle mass but preserved fat mass (Yajnik et al. 2003). There are also direct links between low birth weight and insulin resistance, with evidence that insulin signaling pathways within human skeletal muscle are disrupted as a result of an IUGR pregnancy (Ozanne et al. 2005, Jensen et al. 2008). The effects of low birth weight have also been shown to affect muscle strength. Grip strength is a measure of muscle strength and predictor of quality of life, morbidity, and mortality (Rantanen et al. 2000). Epidemiological studies have shown a positive correlation between birth weight and grip strength in adulthood (Inskip et al. 2007), primarily through the association of lean mass composition (Yliharsila et al. 2007, Ortega et al.
2009). One study comprehensively evaluated grip strength, maximal isometric voluntary contraction (MVC) of the quadriceps femoris, and muscle fatigue before and after an 8-week training program in women who had a ponderal index (PI, a marker of thinness) recorded at the time of birth. Results showed that women born with a PI $<10 \%$, reflecting IUGR during the pregnancy, had $11 \%$ lower grip strength, 9-24\% lower MVC, and a higher rate of muscle fatigue both before and after training compared with women who had a normal PI at the time of birth (Brutsaert et al. 2011). In summary, these findings implicate structural and functional deficits in muscle as major contributors to an increased risk of later-life development of metabolic and cardiovascular diseases in those born with a low birth weight due to IUGR (Barker et al. 2005, Barker 2006, Warner \& Ozanne 2010).

\section{Potential for improving fetal muscle growth in IUGR: future research directions}

Clinical attempts at increasing maternal nutrition during human pregnancy to improve fetal growth have been largely

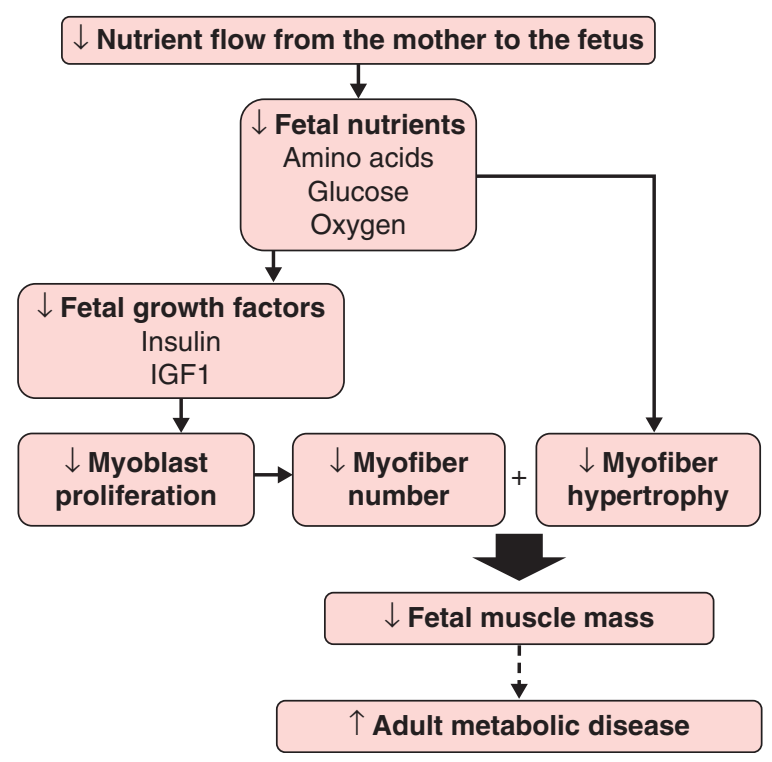

\section{Figure 4}

Proposed mechanisms for reduced skeletal muscle growth during conditions of fetal undernutrition. During conditions of fetal undernutrition (from either maternal dietary restriction or placental insufficiency), nutrient delivery to the fetus (amino acids, glucose, and oxygen) and circulating fetal growth factors (insulin and IGF1) are restricted. The combination of decreased supply of growth factors and nutrients leads to reduced rates of myoblast proliferation and myofiber hypertrophy, ultimately leading to reductions in fetal skeletal muscle mass. The dashed line indicates pathways yet to be determined for how decreased fetal muscle mass contributes to an increased risk of adult metabolic diseases such as obesity, coronary heart disease, and type 2 diabetes. 
unsuccessful. Nutritional supplements with balanced energy and proteins given to pregnant mothers at a high risk of having an IUGR fetus increased birth weight, though whether this promoted fat deposition vs lean mass was not determined (Rush et al. 1980). Current postnatal nutritional interventions for IUGR neonates designed to increase body weight favor fat deposition over muscle growth. The problem is magnified when preterm birth is considered. Almost all extremely low-birth-weight preterm infants experience postnatal growth restriction in the neonatal intensive care unit, even when they are born AGA (Dusick et al. 2003, Ehrenkranz et al. 2006). Preterm birth alone can disrupt normal skeletal muscle development, as preterm infants who are not IUGR have decreased lean mass and increased fat mass at the time of discharge compared with normal full-term infants (Johnson et al. 2012).

Promisingly, however, specific nutrient and growth factor supplementation studies in sheep models of placental insufficiency have yielded encouraging results. Chronic, low-dose IGF1 infusions into IUGR sheep fetuses, either by direct fetal i.v. infusion or by intra-amniotic supplements, improved fetal organ growth (Eremia et al. 2007). Additionally, short-term amino acid infusion given directly to PI-IUGR sheep fetuses increased protein accretion rates by suppressing protein breakdown rates, although whether this affected skeletal muscle growth specifically is yet to be determined (Brown et al. 2012). The use of large animal models of chronic placental insufficiency, such as the PI-IUGR model, allows for the manipulation of fetal substrate and hormone concentrations during critical windows in muscle development. This strategy will provide critical information about the optimal timing and type of supplementation to improve muscle growth in IUGR fetuses, as well as determine cellular deficits that might explain how myoblast proliferation and myofiber hypertrophy become permanently impaired (Fig. 4). Targeting strategies to promote fetal muscle development could improve the potential for postnatal muscle growth, thereby minimizing the risk of developing long-term insulin resistance and chronic metabolic diseases in IUGR individuals.

\section{Declaration of interest}

The author declares that there is no conflict of interest that could be perceived as prejudicing the impartiality of the review reported.

\section{Funding}

This work was funded by the NIH-K12-HD057022 Building Interdisciplinary Research Careers in Women's Health (BIRCWH) and the University of Colorado Center for Women's Health Research.

\section{Acknowledgements}

The author thanks William W Hay Jr, Jacob Friedman, Paul Rozance, Stephanie Thorn, and Leslie Leinwand for their excellent content suggestions and editing support.

\section{References}

Abuzzahab MJ, Schneider A, Goddard A, Grigorescu F, Lautier C, Keller E, Kiess W, Klammt J, Kratzsch J, Osgood D et al. 2003 IGF-I receptor mutations resulting in intrauterine and postnatal growth retardation. New England Journal of Medicine 349 2211-2222. (doi:10.1056/ NEJMoa010107)

Adams GR \& McCue SA 1998 Localized infusion of IGF-I results in skeletal muscle hypertrophy in rats. Journal of Applied Physiology 84 1716-1722.

Allen RE \& Rankin LL 1990 Regulation of satellite cells during skeletal muscle growth and development. Proceedings of the Society for Experimental Biology and Medicine 194 81-86.

Anderson MS, Thamotharan M, Kao D, Devaskar SU, Qiao L, Friedman JE \& Hay WW Jr 2005 Effects of acute hyperinsulinemia on insulin signal transduction and glucose transporters in ovine fetal skeletal muscle. American Journal of Physiology. Regulatory, Integrative and Comparative Physiology 288 R473-R481. (doi:10.1152/ajpregu.00405.2004)

Arroyo JA, Anthony RV \& Galan HL 2008 Decreased placental X-linked inhibitor of apoptosis protein in an ovine model of intrauterine growth restriction. American Journal of Obstetrics and Gynecology 199 80-88. (doi:10.1016/j.ajog.2007.12.017)

Arroyo JA, Brown LD \& Galan HL 2009 Placental mammalian target of rapamycin and related signaling pathways in an ovine model of intrauterine growth restriction. American Journal of Obstetrics and Gynecology 201 616-617. (doi:10.1016/j.ajog.2009.07.031)

Atlantis E, Martin SA, Haren MT, Taylor AW \& Wittert GA 2009 Inverse associations between muscle mass, strength, and the metabolic syndrome. Metabolism 58 1013-1022. (doi:10.1016/j.metabol. 2009.02.027)

Baker J, Workman M, Bedrick E, Frey MA, Hurtado M \& Pearson O 2010 Brains versus brawn: an empirical test of Barker's brain sparing model. American Journal of Human Biology 22 206-215. (doi:10.1002/ajhb. 20979)

Barker DJ 2006 Adult consequences of fetal growth restriction. Clinical Obstetrics and Gynecology 49 270-283. (doi:10.1097/00003081200606000-00009)

Barker DJ, Osmond C, Simmonds SJ \& Wield GA 1993 The relation of small head circumference and thinness at birth to death from cardiovascular disease in adult life. BMJ 306 422-426. (doi:10.1136/ bmj.306.6875.422)

Barker DJ, Eriksson JG, Forsen T \& Osmond C 2002 Fetal origins of adult disease: strength of effects and biological basis. International Journal of Epidemiology 31 1235-1239. (doi:10.1093/ije/31.6.1235)

Barker DJ, Osmond C, Forsen TJ, Kajantie E \& Eriksson JG 2005 Trajectories of growth among children who have coronary events as adults. New England Journal of Medicine 353 1802-1809. (doi:10.1056/ NEJMoa044160)

Barker DJ, Gelow J, Thornburg K, Osmond C, Kajantie E \& Eriksson JG 2010 The early origins of chronic heart failure: impaired placental growth and initiation of insulin resistance in childhood. European Journal of Heart Failure 12 819-825. (doi:10.1093/eurjhf/hfq069)

Barry JS, Rozance PJ \& Anthony RV 2008 An animal model of placental insufficiency-induced intrauterine growth restriction. Seminars in Perinatology 32 225-230. (doi:10.1053/j.semperi.2007.11.004)

Basaria S \& Bhasin S 2012 Targeting the skeletal muscle-metabolism axis in prostate-cancer therapy. New England Journal of Medicine $\mathbf{3 6 7}$ 965-967. (doi:10.1056/NEJMcibr1203160) 
Battaglia FC \& Lubchenco LO 1967 A practical classification of newborn infants by weight and gestational age. Journal of Pediatrics 71 159-163. (doi:10.1016/S0022-3476(67)80066-0)

Bauer R, Walter B, Brust P, Fuchtner F \& Zwiener U 2003 Impact of asymmetric intrauterine growth restriction on organ function in newborn piglets. European Journal of Obstetrics, Gynecology, and Reproductive Biology 110(Suppl 1) S40-S49. (doi:10.1016/S03012115(03)00171-4)

Bauer R, Gedrange T, Bauer K \& Walter B 2006 Intrauterine growth restriction induces increased capillary density and accelerated type I fiber maturation in newborn pig skeletal muscles. Journal of Perinatal Medicine 34 235-242. (doi:10.1515/JPM.2006.042)

Beermann DH, Cassens RG \& Hausman GJ 1978 A second look at fiber type differentiation in porcine skeletal muscle. Journal of Animal Science $\mathbf{4 6}$ 125-132.

Bell AW, Wilkening RB \& Meschia G 1987 Some aspects of placental function in chronically heat-stressed ewes. Journal of Developmental Physiology 9 17-29.

Beltrand J, Verkauskiene R, Nicolescu R, Sibony O, Gaucherand P, Chevenne D, Claris O \& Levy-Marchal C 2008 Adaptive changes in neonatal hormonal and metabolic profiles induced by fetal growth restriction. Journal of Clinical Endocrinology and Metabolism 93 4027-4032. (doi:10.1210/jc.2008-0562)

Berkes CA \& Tapscott SJ 2005 MyoD and the transcriptional control of myogenesis. Seminars in Cell \& Developmental Biology 16 585-595. (doi:10.1016/j.semcdb.2005.07.006)

Biolo G, Zhang XJ \& Wolfe RR 1995 Role of membrane transport in interorgan amino acid flow between muscle and small intestine. Metabolism 44 719-724. (doi:10.1016/0026-0495(95)90183-3)

Biolo G, Fleming RY, Maggi SP, Nguyen TT, Herndon DN \& Wolfe RR 2002 Inverse regulation of protein turnover and amino acid transport in skeletal muscle of hypercatabolic patients. Journal of Clinical Endocrinology and Metabolism 87 3378-3384. (doi:10.1210/jcem.87.7.8699)

Bonaldo P \& Sandri M 2013 Cellular and molecular mechanisms of muscle atrophy. Disease Models \& Mechanisms 6 25-39. (doi:10.1242/ dmm.010389)

de Boo HA, van Zijl PL, Smith DE, Kulik W, Lafeber HN \& Harding JE 2005 Arginine and mixed amino acids increase protein accretion in the growth-restricted and normal ovine fetus by different mechanisms. Pediatric Research 58 270-277. (doi:10.1203/01.PDR.0000169977. 48609.55)

Bostrom P, Wu J, Jedrychowski MP, Korde A, Ye L, Lo JC, Rasbach KA, Bostrom EA, Choi JH, Long JZ et al. 2012 A PGC1- $\alpha$-dependent myokine that drives brown-fat-like development of white fat and thermogenesis. Nature 481 463-468. (doi:10.1038/nature10777)

Boyle DW, Denne SC, Moorehead H, Lee WH, Bowsher RR \& Liechty EA 1998 Effect of rhIGF-I infusion on whole fetal and fetal skeletal muscle protein metabolism in sheep. American Journal of Physiology $\mathbf{2 7 5}$ E1082-E1091.

Boyle JP, Thompson TJ, Gregg EW, Barker LE \& Williamson DF 2010 Projection of the year 2050 burden of diabetes in the US adult population: dynamic modeling of incidence, mortality, and prediabetes prevalence. Population Health Metrics 8 29. (doi:10.1186/ 1478-7954-8-29)

Braun T \& Gautel M 2011 Transcriptional mechanisms regulating skeletal muscle differentiation, growth and homeostasis. Nature Reviews. Molecular Cell Biology 12 349-361. (doi:10.1038/nrm3118)

Brown LD, Rozance PJ, Barry JS, Friedman JE \& Hay WW Jr 2009 Insulin is required for amino acid stimulation of dual pathways for translational control in skeletal muscle in the late-gestation ovine fetus. American Journal of Physiology. Endocrinology and Metabolism 296 E56-E63. (doi:10.1152/ajpendo.90310.2008)

Brown LD, Rozance PJ, Thorn SR, Friedman JE \& Hay WW Jr 2012 Acute supplementation of amino acids increases net protein accretion in IUGR fetal sheep. American Journal of Physiology. Endocrinology and Metabolism 303 E352-E364. (doi:10.1152/ajpendo.00059.2012)
Brutsaert TD, Tamvada KH, Kiyamu M, White DD \& Gage TB 2011 Low ponderal index is associated with decreased muscle strength and fatigue resistance in college-aged women. Early Human Development $\mathbf{8 7}$ 663-669. (doi:10.1016/j.earlhumdev.2011.05.006)

Cassar-Malek I, Langlois N, Picard B \& Geay Y 1999 Regulation of bovine satellite cell proliferation and differentiation by insulin and triiodothyronine. Domestic Animal Endocrinology 17 373-388. (doi:10.1016/ S0739-7240(99)00055-7)

Cetin I, Marconi AM, Corbetta C, Lanfranchi A, Baggiani AM, Battaglia FC \& Pardi G 1992 Fetal amino acids in normal pregnancies and in pregnancies complicated by intrauterine growth retardation. Early Human Development 29 183-186. (doi:10.1016/0378-3782(92)90136-5)

Cindrova-Davies T, Herrera EA, Niu Y, Kingdom J, Giussani DA \& Burton GJ 2013 Reduced cystathionine $\gamma$-lyase and increased miR-21 expression are associated with increased vascular resistance in growth-restricted pregnancies: hydrogen sulfide as a placental vasodilator. American Journal of Pathology 182 1448-1458. (doi:10.1016/j.ajpath.2013.01.001)

Coleman ME, DeMayo F, Yin KC, Lee HM, Geske R, Montgomery C \& Schwartz RJ 1995 Myogenic vector expression of insulin-like growth factor I stimulates muscle cell differentiation and myofiber hypertrophy in transgenic mice. Journal of Biological Chemistry 270 12109-12116. (doi:10.1074/jbc.270.20.12109)

Costello PM, Rowlerson A, Astaman NA, Anthony FE, Sayer AA, Cooper C, Hanson MA \& Green LR 2008 Peri-implantation and late gestation maternal undernutrition differentially affect fetal sheep skeletal muscle development. Journal of Physiology 586 2371-2379. (doi:10.1113/ jphysiol.2008.150987)

Curhan GC, Willett WC, Rimm EB, Spiegelman D, Ascherio AL \& Stampfer MJ 1996 Birth weight and adult hypertension, diabetes mellitus, and obesity in US men. Circulation 94 3246-3250. (doi:10.1161/01.CIR.94. 12.3246)

Daniel ZC, Brameld JM, Craigon J, Scollan ND \& Buttery PJ 2007 Effect of maternal dietary restriction during pregnancy on lamb carcass characteristics and muscle fiber composition. Journal of Animal Science 85 1565-1576. (doi:10.2527/jas.2006-743)

Davis TA, Fiorotto ML, Burrin DG, Reeds PJ, Nguyen HV, Beckett PR, Vann RC \& O'Connor PM 2002 Stimulation of protein synthesis by both insulin and amino acids is unique to skeletal muscle in neonatal pigs. American Journal of Physiology. Endocrinology and Metabolism 282 E880-E890.

De Blasio MJ, Gatford KL, Robinson JS \& Owens JA 2007 Placental restriction of fetal growth reduces size at birth and alters postnatal growth, feeding activity, and adiposity in the young lamb. American Journal of Physiology. Regulatory, Integrative and Comparative Physiology 292 R875-R886. (doi:10.1152/ajpregu.00430.2006)

DeFronzo RA, Jacot E, Jequier E, Maeder E, Wahren J \& Felber JP 1981 The effect of insulin on the disposal of intravenous glucose. Results from indirect calorimetry and hepatic and femoral venous catheterization. Diabetes 30 1000-1007. (doi:10.2337/diab.30.12.1000)

De Jesus LC, Pappas A, Shankaran S, Li L, Das A, Bell EF, Stoll BJ, Laptook AR, Walsh MC, Hale EC et al. 2013 Outcomes of small for gestational age infants born at $<27$ weeks' gestation. Journal of Pediatrics 163 55-60. (doi:10.1016/j.jpeds.2012.12.097)

Desai M, Crowther NJ, Lucas A \& Hales CN 1996 Organ-selective growth in the offspring of protein-restricted mothers. British Journal of Nutrition $\mathbf{7 6}$ 591-603. (doi:10.1079/BJN19960065)

Dodd KM \& Tee AR 2012 Leucine and mTOR: a complex relationship. American Journal of Physiology. Endocrinology and Metabolism $\mathbf{3 0 2}$ E1329-E1342. (doi:10.1152/ajpendo.00525.2011)

Doherty TJ 2003 Invited review: Aging and sarcopenia. Journal of Applied Physiology 95 1717-1727.

Dong J, Qiu H, Garcia-Barrio M, Anderson J \& Hinnebusch AG 2000 Uncharged tRNA activates GCN2 by displacing the protein kinase moiety from a bipartite tRNA-binding domain. Molecular Cell 6 269-279. (doi:10.1016/S1097-2765(00)00028-9) http://joe.endocrinology-journals.org DOI: 10.1530/JOE-13-0567
() 2014 Society for Endocrinology Printed in Great Britain 
Drummond MJ \& Rasmussen BB 2008 Leucine-enriched nutrients and the regulation of mammalian target of rapamycin signalling and human skeletal muscle protein synthesis. Current Opinion in Clinical Nutrition and Metabolic Care 11 222-226. (doi:10.1097/MCO.0b013e3282fa17fb)

Du M, Tong J, Zhao J, Underwood KR, Zhu M, Ford SP \& Nathanielsz PW 2010 Fetal programming of skeletal muscle development in ruminant animals. Journal of Animal Science 88 E51-E60. (doi:10.2527/jas. 2009-2311)

Du M, Huang Y, Das AK, Yang Q, Duarte MS, Dodson MV \& Zhu MJ 2013 Meat Science and Muscle Biology Symposium: manipulating mesenchymal progenitor cell differentiation to optimize performance and carcass value of beef cattle. Journal of Animal Science 91 1419-1427. (doi:10.2527/jas.2012-5670)

Dusick AM, Poindexter BB, Ehrenkranz RA \& Lemons JA 2003 Growth failure in the preterm infant: can we catch up? Seminars in Perinatology 27 302-310. (doi:10.1016/S0146-0005(03)00044-2)

Dwyer CM \& Stickland NC $1992 a$ Does the anatomical location of a muscle affect the influence of undernutrition on muscle fibre number? Journal of Anatomy 181 373-376.

Dwyer CM \& Stickland NC $1992 b$ The effects of maternal undernutrition on maternal and fetal serum insulin-like growth factors, thyroid hormones and cortisol in the guinea pig. Journal of Developmental Physiology 18 303-313.

Dwyer CM, Fletcher JM \& Stickland NC 1993 Muscle cellularity and postnatal growth in the pig. Journal of Animal Science 71 3339-3343.

Dwyer CM, Stickland NC \& Fletcher JM 1994 The influence of maternal nutrition on muscle fiber number development in the porcine fetus and on subsequent postnatal growth. Journal of Animal Science 72 911-917.

Dwyer CM, Madgwick AJ, Ward SS \& Stickland NC 1995 Effect of maternal undernutrition in early gestation on the development of fetal myofibres in the guinea-pig. Reproduction, Fertility, and Development 7 1285-1292. (doi:10.1071/RD9951285)

Ehrenkranz RA, Dusick AM, Vohr BR, Wright LL, Wrage LA \& Poole WK 2006 Growth in the neonatal intensive care unit influences neurodevelopmental and growth outcomes of extremely low birth weight infants. Pediatrics 117 1253-1261. (doi:10.1542/peds.2005-1368)

Eremia SC, de Boo HA, Bloomfield FH, Oliver MH \& Harding JE 2007 Fetal and amniotic insulin-like growth factor-I supplements improve growth rate in intrauterine growth restriction fetal sheep. Endocrinology 148 2963-2972. (doi:10.1210/en.2006-1701)

Fahey AJ, Brameld JM, Parr T \& Buttery PJ 2005a Ontogeny of factors associated with proliferation and differentiation of muscle in the ovine fetus. Journal of Animal Science 83 2330-2338.

Fahey AJ, Brameld JM, Parr T \& Buttery PJ 2005 $b$ The effect of maternal undernutrition before muscle differentiation on the muscle fiber development of the newborn lamb. Journal of Animal Science $\mathbf{8 3}$ 2564-2571.

Figueras F \& Gardosi J 2011 Intrauterine growth restriction: new concepts in antenatal surveillance, diagnosis, and management. American Journal of Obstetrics and Gynecology 204 288-300. (doi:10.1016/j.ajog. 2010.08.055)

Ford SP, Hess BW, Schwope MM, Nijland MJ, Gilbert JS, Vonnahme KA, Means WJ, Han H \& Nathanielsz PW 2007 Maternal undernutrition during early to mid-gestation in the ewe results in altered growth, adiposity, and glucose tolerance in male offspring. Journal of Animal Science 85 1285-1294. (doi:10.2527/jas.2005-624)

Fowden AL, Hughes P \& Comline RS 1989 The effects of insulin on the growth rate of the sheep fetus during late gestation. Quarterly Journal of Experimental Physiology 74 703-714.

Frost RA \& Lang CH 2012 Multifaceted role of insulin-like growth factors and mammalian target of rapamycin in skeletal muscle. Endocrinology and Metabolism Clinics of North America 41 297-322. (doi:10.1016/j.ecl. 2012.04.012)

Gale CR, Martyn CN, Kellingray S, Eastell R \& Cooper C 2001 Intrauterine programming of adult body composition. Journal of Clinical
Endocrinology and Metabolism 86 267-272. (doi:10.1210/jcem.86. 1.7155)

Gaster M, Kristensen SR, Beck-Nielsen H \& Schroder HD 2001 A cellular model system of differentiated human myotubes. APMIS 109 735-744. (doi:10.1034/j.1600-0463.2001.d01-140.x)

Gerrard DE \& Grant AL 2003 Myogenesis. In Principles of Animal Growth and Development, pp 63-75. Eds DE Gerrard \& AL Grant. Dubuque: Kendall/Hunt Publishing Company.

Goodman CA, Mayhew DL \& Hornberger TA 2011 Recent progress toward understanding the molecular mechanisms that regulate skeletal muscle mass. Cellular Signalling 23 1896-1906. (doi:10.1016/j.cellsig.2011. 07.013)

Greenwood PL, Slepetis RM, Hermanson JW \& Bell AW 1999 Intrauterine growth retardation is associated with reduced cell cycle activity, but not myofibre number, in ovine fetal muscle. Reproduction, Fertility, and Development 11 281-291. (doi:10.1071/RD99054)

Greenwood PL, Hunt AS, Hermanson JW \& Bell AW 2000 Effects of birth weight and postnatal nutrition on neonatal sheep: II. Skeletal muscle growth and development. Journal of Animal Science 78 50-61.

Grobet L, Martin LJ, Poncelet D, Pirottin D, Brouwers B, Riquet J, Schoeberlein A, Dunner S, Menissier F, Massabanda J et al. 1997 A deletion in the bovine myostatin gene causes the doublemuscled phenotype in cattle. Nature Genetics 17 71-74. (doi:10.1038/ ng0997-71)

Gulve EA \& Dice JF 1989 Regulation of protein synthesis and degradation in L8 myotubes. Effects of serum, insulin and insulin-like growth factors. Biochemical Journal $260377-387$.

Guo K, Wang J, Andres V, Smith RC \& Walsh K 1995 MyoD-induced expression of p21 inhibits cyclin-dependent kinase activity upon myocyte terminal differentiation. Molecular and Cellular Biology $\mathbf{1 5}$ 3823-3829.

Guo T, Bond ND, Jou W, Gavrilova O, Portas J \& McPherron AC 2012 Myostatin inhibition prevents diabetes and hyperphagia in a mouse model of lipodystrophy. Diabetes 61 2414-2423. (doi:10.2337/ db11-0915)

Hales CN, Barker DJ, Clark PM, Cox LJ, Fall C, Osmond C \& Winter PD 1991 Fetal and infant growth and impaired glucose tolerance at age 64. BMJ 303 1019-1022. (doi:10.1136/bmj.303.6809.1019)

Han JM, Jeong SJ, Park MC, Kim G, Kwon NH, Kim HK, Ha SH, Ryu SH \& Kim S 2012 Leucyl-tRNA synthetase is an intracellular leucine sensor for the mTORC1-signaling pathway. Cell 149 410-424. (doi:10.1016/j.cell. 2012.02.044)

Hardie DG, Ross FA \& Hawley SA 2012 AMPK: a nutrient and energy sensor that maintains energy homeostasis. Nature Reviews. Molecular Cell Biology 13 251-262. (doi:10.1038/nrm3311)

Harper JM, Soar JB \& Buttery PJ 1987 Changes in protein metabolism of ovine primary muscle cultures on treatment with growth hormone, insulin, insulin-like growth factor I or epidermal growth factor. Journal of Endocrinology 112 87-96. (doi:10.1677/joe.0.1120087)

Hediger ML, Overpeck MD, Kuczmarski RJ, McGlynn A, Maurer KR \& Davis WW 1998 Muscularity and fatness of infants and young children born small- or large-for-gestational-age. Pediatrics 102 E60. (doi:10.1542/peds.102.5.e60)

Iniguez G, Ong K, Bazaes R, Avila A, Salazar T, Dunger D \& Mericq V 2006 Longitudinal changes in insulin-like growth factor-I, insulin sensitivity, and secretion from birth to age three years in small-forgestational-age children. Journal of Clinical Endocrinology and Metabolism 91 4645-4649. (doi:10.1210/jc.2006-0844)

Inskip HM, Godfrey KM, Martin HJ, Simmonds SJ, Cooper C \& Sayer AA 2007 Size at birth and its relation to muscle strength in young adult women. Journal of Internal Medicine 262 368-374. (doi:10.1111/j.13652796.2007.01812.x)

Jensen CB, Storgaard H, Madsbad S, Richter EA \& Vaag AA 2007 Altered skeletal muscle fiber composition and size precede whole-body insulin resistance in young men with low birth weight. Journal of Clinical 
Endocrinology and Metabolism 92 1530-1534. (doi:10.1210/jc.20062360)

Jensen CB, Martin-Gronert MS, Storgaard H, Madsbad S, Vaag A \& Ozanne SE 2008 Altered PI3-kinase/Akt signalling in skeletal muscle of young men with low birth weight. PLOS ONE 3 e3738. (doi:10.1371/journal.pone. 0003738)

Jimenez-Chillaron JC \& Patti ME 2007 To catch up or not to catch up: is this the question? Lessons from animal models Current Opinion in Endocrinology, Diabetes, and Obesity 14 23-29. (doi:10.1097/MED. Ob013e328013da8e)

Johnson MJ, Wootton SA, Leaf AA \& Jackson AA 2012 Preterm birth and body composition at term equivalent age: a systematic review and meta-analysis. Pediatrics 130 e640-e649. (doi:10.1542/peds.2011-3379)

Kadar L, Albertsson M, Areberg J, Landberg T \& Mattsson S 2000 The prognostic value of body protein in patients with lung cancer. Annals of New York Academy of Sciences 904 584-591. (doi:10.1111/j.1749-6632. 2000.tb06520.x)

Kahn HS, Narayan KM, Williamson DF \& Valdez R 2000 Relation of birth weight to lean and fat thigh tissue in young men. International Journal of Obesity and Related Metabolic Disorders 24 667-672. (doi:10.1038/sj.ijo. 0801211)

Kalista S, Schakman O, Gilson H, Lause P, Demeulder B, Bertrand L, Pende M \& Thissen JP 2012 The type 1 insulin-like growth factor receptor (IGF-IR) pathway is mandatory for the follistatin-induced skeletal muscle hypertrophy. Endocrinology 153 241-253. (doi:10.1210/en. 2011-1687)

Kensara OA, Wootton SA, Phillips DI, Patel M, Jackson AA \& Elia M 2005 Fetal programming of body composition: relation between birth weight and body composition measured with dual-energy X-ray absorptiometry and anthropometric methods in older Englishmen. American Journal of Clinical Nutrition 82 980-987.

Lapillonne A, Braillon P, Claris O, Chatelain PG, Delmas PD \& Salle BL 1997 Body composition in appropriate and in small for gestational age infants. Acta Paediatrica 86 196-200. (doi:10.1111/j.1651-2227.1997. tb08868.x)

Laplante M \& Sabatini DM 2012 mTOR signaling in growth control and disease. Cell 149 274-293. (doi:10.1016/j.cell.2012.03.017)

Larciprete G, Valensise H, Di Pierro G, Vasapollo B, Casalino B, Arduini D, Jarvis S \& Cirese E 2005 Intrauterine growth restriction and fetal body composition. Ultrasound in Obstetrics \& Gynecology 26 258-262. (doi:10.1002/uog.1980)

Lassarre C, Hardouin S, Daffos F, Forestier F, Frankenne F \& Binoux M 1991 Serum insulin-like growth factors and insulin-like growth factor binding proteins in the human fetus. Relationships with growth in normal subjects and in subjects with intrauterine growth retardation. Pediatric Research 29 219-225. (doi:10.1203/00006450-19910300000001)

Lee WH, Gaylord TD, Bowsher RR, Hlaing M, Moorehead H \& Liechty EA 1997 Nutritional regulation of circulating insulin-like growth factors (IGFs) and their binding proteins in the ovine fetus. Endocrine Journal 44 163-173. (doi:10.1507/endocrj.44.163)

Leger J, Oury JF, Noel M, Baron S, Benali K, Blot P \& Czernichow P 1996 Growth factors and intrauterine growth retardation. I. Serum growth hormone, insulin-like growth factor (IGF)-I, IGF-II, and IGF binding protein 3 levels in normally grown and growth-retarded human fetuses during the second half of gestation. Pediatric Research 40 94-100. (doi:10.1203/00006450-199607000-00017)

Lemons JA, Ridenour R \& Orsini EN 1979 Congenital absence of the pancreas and intrauterine growth retardation. Pediatrics 64 255-257.

Leos RA, Anderson MJ, Chen X, Pugmire J, Anderson KA \& Limesand SW 2010 Chronic exposure to elevated norepinephrine suppresses insulin secretion in fetal sheep with placental insufficiency and intrauterine growth restriction. American Journal of Physiology. Endocrinology and Metabolism 298 E770-E778. (doi:10.1152/ajpendo.00494.2009)

Leprivier G, Remke M, Rotblat B, Dubuc A, Mateo AR, Kool M, Agnihotri S, El-Naggar A, Yu B, Somasekharan SP et al. 2013 The eEF2 kinase confers resistance to nutrient deprivation by blocking translation elongation. Cell 153 1064-1079. (doi:10.1016/j.cell.2013.04.055)

Limesand SW, Rozance PJ, Zerbe GO, Hutton JC \& Hay WW Jr 2006 Attenuated insulin release and storage in fetal sheep pancreatic islets with intrauterine growth restriction. Endocrinology 147 1488-1497. (doi:10.1210/en.2005-0900)

Liu JP, Baker J, Perkins AS, Robertson EJ \& Efstratiadis A 1993 Mice carrying null mutations of the genes encoding insulin-like growth factor I (Igf-1) and type 1 IGF receptor (Igf1r). Cell 75 59-72. (doi:10.1016/s00928674(05)80084-4)

Liu W, Shen SM, Zhao XY \& Chen GQ 2012 Targeted genes and interacting proteins of hypoxia inducible factor-1. International Journal of Biochemistry and Molecular Biology 3 165-178.

Loos RJ, Beunen G, Fagard R, Derom C \& Vlietinck R 2001 Birth weight and body composition in young adult men - a prospective twin study. International Journal of Obesity and Related Metabolic Disorders 25 1537-1545. (doi:10.1038/sj.ijo.0801743)

Loos RJ, Beunen G, Fagard R, Derom C \& Vlietinck R 2002 Birth weight and body composition in young women: a prospective twin study. American Journal of Clinical Nutrition 75 676-682.

Louey S, Cock ML \& Harding R 2005 Long term consequences of low birthweight on postnatal growth, adiposity and brain weight at maturity in sheep. Journal of Reproduction and Development 51 59-68. (doi:10.1262/jrd.51.59)

Macko AR, Yates DT, Chen X, Green AS, Kelly AC, Brown LD \& Limesand SW 2013 Elevated plasma norepinephrine inhibits insulin secretion, but adrenergic blockade reveals enhanced $\beta$-cell responsiveness in an ovine model of placental insufficiency at 0.7 of gestation. Journal of Developmental Origins of Health and Disease 4 402-410. (doi:10.1017/S2040174413000093)

Mammucari C, Milan G, Romanello V, Masiero E, Rudolf R, Del Piccolo P, Burden SJ, Di Lisi R, Sandri C, Zhao J et al. 2007 FoxO3 controls autophagy in skeletal muscle in vivo. Cell Metabolism 6 458-471. (doi:10.1016/j.cmet.2007.11.001)

Marconi AM \& Paolini CL 2008 Nutrient transport across the intrauterine growth-restricted placenta. Seminars in Perinatology 32 178-181. (doi:10.1053/j.semperi.2008.02.007)

Marconi AM, Paolini CL, Zerbe G \& Battaglia FC 2006 Lactacidemia in intrauterine growth restricted (IUGR) pregnancies: relationship to clinical severity, oxygenation and placental weight. Pediatric Research 59 570-574. (doi:10.1203/01.pdr.0000205477.70391.3e)

Mavalli MD, DiGirolamo DJ, Fan Y, Riddle RC, Campbell KS, van Groen T, Frank SJ, Sperling MA, Esser KA, Bamman MM et al. 2010 Distinct growth hormone receptor signaling modes regulate skeletal muscle development and insulin sensitivity in mice. Journal of Clinical Investigation 120 4007-4020. (doi:10.1172/JCI42447)

McKeigue PM, Lithell HO \& Leon DA 1998 Glucose tolerance and resistance to insulin-stimulated glucose uptake in men aged 70 years in relation to size at birth. Diabetologia 41 1133-1138. (doi:10.1007/ s001250051042)

McPherron AC, Lawler AM \& Lee SJ 1997 Regulation of skeletal muscle mass in mice by a new TGF- $\beta$ superfamily member. Nature 387 83-90. (doi:10.1038/387083a0)

Mifflin MD, St Jeor ST, Hill LA, Scott BJ, Daugherty SA \& Koh YO 1990 A new predictive equation for resting energy expenditure in healthy individuals. American Journal of Clinical Nutrition $51241-247$.

Milley JR 1994 Effects of insulin on ovine fetal leucine kinetics and protein metabolism. Journal of Clinical Investigation 93 1616-1624. (doi:10.1172/JCI117142)

Molkentin JD \& Olson EN 1996 Defining the regulatory networks for muscle development. Current Opinion in Genetics \& Development 6 445-453. (doi:10.1016/S0959-437X(96)80066-9)

Molteni RA, Stys SJ \& Battaglia FC 1978 Relationship of fetal and placental weight in human beings: fetal/placental weight ratios at various gestational ages and birth weight distributions. Journal of Reproductive Medicine 21 327-334. 
Moss FP \& Leblond CP 1971 Satellite cells as the source of nuclei in muscles of growing rats. Anatomical Record 170 421-435. (doi:10.1002/ ar.1091700405)

Naito T, Kuma A \& Mizushima N 2013 Differential contribution of insulin and amino acids to the mTORC1-autophagy pathway in the liver and muscle. Journal of Biological Chemistry 288 21074-21081. (doi:10.1074/ jbc.M113.456228)

Nelson KM, Weinsier RL, Long CL \& Schutz Y 1992 Prediction of resting energy expenditure from fat-free mass and fat mass. American Journal of Clinical Nutrition 56 848-856.

Newsholme EA 1978 Substrate cycles: their metabolic, energetic and thermic consequences in man. Biochemical Society Symposium 183-205.

Nicolini U, Hubinont C, Santolaya J, Fisk NM \& Rodeck CH 1990 Effects of fetal intravenous glucose challenge in normal and growth retarded fetuses. Hormone and Metabolic Research 22 426-430. (doi:10.1055/ s-2007-1004939)

O'Connor PM, Kimball SR, Suryawan A, Bush JA, Nguyen HV, Jefferson LS $\&$ Davis TA 2003a Regulation of translation initiation by insulin and amino acids in skeletal muscle of neonatal pigs. American Journal of Physiology. Endocrinology and Metabolism 285 E40-E53.

O'Connor PM, Bush JA, Suryawan A, Nguyen HV \& Davis TA $2003 b$ Insulin and amino acids independently stimulate skeletal muscle protein synthesis in neonatal pigs. American Journal of Physiology. Endocrinology and Metabolism 284 E110-E119.

Ogden CL, Carroll MD, Kit BK \& Flegal KM 2012 Prevalence of obesity in the United States, 2009-2010. NCHS Data Brief 82 1-8.

Ortega FB, Labayen I, Ruiz JR, Martin-Matillas M, Vicente-Rodriguez G, Redondo C, Warnberg J, Gutierrez A, Sjostrom M, Castillo MJ et al. 2009 Are muscular and cardiovascular fitness partially programmed at birth? Role of body composition Journal of Pediatrics 154 61-66. (doi:10.1016/ j.jpeds.2008.07.041)

Osgerby JC, Wathes DC, Howard D \& Gadd TS 2002 The effect of maternal undernutrition on ovine fetal growth. Journal of Endocrinology 173 131-141. (doi:10.1677/joe.0.1730131)

Owens JA, Kind KL, Carbone F, Robinson JS \& Owens PC 1994 Circulating insulin-like growth factors-I and -II and substrates in fetal sheep following restriction of placental growth. Journal of Endocrinology 140 5-13. (doi:10.1677/joe.0.1400005)

Ozanne SE, Jensen CB, Tingey KJ, Storgaard H, Madsbad S \& Vaag AA 2005 Low birthweight is associated with specific changes in muscle insulinsignalling protein expression. Diabetologia 48 547-552. (doi:10.1007/ s00125-005-1669-7)

Padoan A, Rigano S, Ferrazzi E, Beaty BL, Battaglia FC \& Galan HL 2004 Differences in fat and lean mass proportions in normal and growthrestricted fetuses. American Journal of Obstetrics and Gynecology 191 1459-1464. (doi:10.1016/j.ajog.2004.06.045)

Paolini CL, Marconi AM, Ronzoni S, Di Noio M, Fennessey PV, Pardi G \& Battaglia FC 2001 Placental transport of leucine, phenylalanine, glycine, and proline in intrauterine growth-restricted pregnancies. Journal of Clinical Endocrinology and Metabolism 86 5427-5432. (doi:10.1210/jcem.86.11.8036)

Pardi G, Cetin I, Marconi AM, Lanfranchi A, Bozzetti P, Ferrazzi E, Buscaglia M \& Battaglia FC 1993 Diagnostic value of blood sampling in fetuses with growth retardation. New England Journal of Medicine 328 692-696. (doi:10.1056/NEJM199303113281004)

Pette D \& Staron RS 2001 Transitions of muscle fiber phenotypic profiles. Histochemistry and Cell Biology 115 359-372.

Phipps K, Barker DJ, Hales CN, Fall CH, Osmond C \& Clark PM 1993 Fetal growth and impaired glucose tolerance in men and women. Diabetologia 36 225-228. (doi:10.1007/BF00399954)

Pittenger MF, Mackay AM, Beck SC, Jaiswal RK, Douglas R, Mosca JD, Moorman MA, Simonetti DW, Craig S \& Marshak DR 1999 Multilineage potential of adult human mesenchymal stem cells. Science $\mathbf{2 8 4}$ 143-147. (doi:10.1126/science.284.5411.143)
Platz E \& Newman R 2008 Diagnosis of IUGR: traditional biometry. Seminars in Perinatology 32 140-147. (doi:10.1053/j.semperi. 2008.02.002)

Poindexter BB, Karn CA, Ahlrichs JA, Wang J, Leitch CA, Liechty EA \& Denne SC 1997 Amino acids suppress proteolysis independent of insulin throughout the neonatal period. American Journal of Physiology 272 E592-E599.

Pollack RN \& Divon MY 1992 Intrauterine growth retardation: definition, classification, and etiology. Clinical Obstetrics and Gynecology 35 99-107. (doi:10.1097/00003081-199203000-00015)

Poore KR \& Fowden AL 2004 Insulin sensitivity in juvenile and adult Large White pigs of low and high birthweight. Diabetologia 47 340-348. (doi:10.1007/s00125-003-1305-3)

Powell SE \& Aberle ED 1980 Effects of birth weight on growth and carcass composition of swine. Journal of Animal Science $\mathbf{5 0} 860-868$.

Powell-Braxton L, Hollingshead P, Warburton C, Dowd M, Pitts-Meek S, Dalton D, Gillett N \& Stewart TA 1993 IGF-I is required for normal embryonic growth in mice. Genes and Development 7 2609-2617. (doi:10.1101/gad.7.12b.2609)

Prakash YS, Fournier M \& Sieck GC 1993 Effects of prenatal undernutrition on developing rat diaphragm. Journal of Applied Physiology $\mathbf{7 5}$ 1044-1052.

Racca AW, Beck AE, Rao VS, Flint GV, Lundy SD, Born DE, Bamshad MJ \& Regnier M 2013 Contractility and kinetics of human fetal and human adult skeletal muscle. Journal of Physiology 591 3049-3061. (doi:10.1113/jphysiol.2013.252650)

Rantanen T, Harris T, Leveille SG, Visser M, Foley D, Masaki K \& Guralnik JM 2000 Muscle strength and body mass index as long-term predictors of mortality in initially healthy men. Journals of Gerontology. Series A, Biological Sciences and Medical Sciences 55 M168-M173. (doi:10.1093/ gerona/55.3.M168)

Rao SS \& Kohtz DS 1995 Positive and negative regulation of D-type cyclin expression in skeletal myoblasts by basic fibroblast growth factor and transforming growth factor $\beta$. A role for cyclin D1 in control of myoblast differentiation. Journal of Biological Chemistry $2704093-4100$. (doi:10.1074/jbc.270.34.20011)

Ravelli AC, van Der Meulen JH, Osmond C, Barker DJ \& Bleker OP 1999 Obesity at the age of $50 \mathrm{y}$ in men and women exposed to famine prenatally. American Journal of Clinical Nutrition 70 811-816.

Regnault TR, Orbus RJ, Battaglia FC, Wilkening RB \& Anthony RV 1999 Altered arterial concentrations of placental hormones during maximal placental growth in a model of placental insufficiency. Journal of Endocrinology 162 433-442. (doi:10.1677/joe.0.1620433)

Regnault TR, Orbus RJ, de Vrijer B, Davidsen ML, Galan HL, Wilkening RB \& Anthony RV 2002 Placental expression of VEGF, PlGF and their receptors in a model of placental insufficiency-intrauterine growth restriction (PI-IUGR). Placenta 23 132-144. (doi:10.1053/plac.2001. 0757)

Regnault TR, de Vrijer B, Galan HL, Wilkening RB, Battaglia FC \& Meschia G 2007 Development and mechanisms of fetal hypoxia in severe fetal growth restriction. Placenta 28 714-723. (doi:10.1016/j.placenta.2006. 06.007)

Regnault TR, de Vrijer B, Galan HL, Wilkening RB, Battaglia FC \& Meschia G 2013 Umbilical uptakes and transplacental concentration ratios of amino acids in severe fetal growth restriction. Pediatric Research $\mathbf{7 3}$ 602-611. (doi:10.1038/pr.2013.30)

Reynolds RM, Bass KD \& Thureen PJ 2008 Achieving positive protein balance in the immediate postoperative period in neonates undergoing abdominal surgery. Journal of Pediatrics 152 63-67. (doi:10.1016/ j.jpeds.2007.05.042)

Rich-Edwards JW, Colditz GA, Stampfer MJ, Willett WC, Gillman MW, Hennekens CH, Speizer FE \& Manson JE 1999 Birthweight and the risk for type 2 diabetes mellitus in adult women. Annals of Internal Medicine 130 278-284. (doi:10.7326/0003-4819-130-4_Part_1-19990216000005) 
Rosenthal SM \& Cheng ZQ 1995 Opposing early and late effects of insulinlike growth factor I on differentiation and the cell cycle regulatory retinoblastoma protein in skeletal myoblasts. PNAS 92 10307-10311. (doi:10.1073/pnas.92.22.10307)

Rowe RW \& Goldspink G 1969 Muscle fibre growth in five different muscles in both sexes of mice. Journal of Anatomy 104 519-530.

Rush D, Stein Z \& Susser M 1980 A randomized controlled trial of prenatal nutritional supplementation in New York City. Pediatrics 65 683-697.

Russell RG \& Oteruelo FT 1981 An ultrastructural study of the differentiation of skeletal muscle in the bovine fetus. Anatomy and Embryology 162 403-417. (doi:10.1007/BF00301866)

Saad S, Peter M \& Dechant R 2013 In scarcity and abundance: metabolic signals regulating cell growth. Physiology 28 298-309. (doi:10.1152/ physiol.00005.2013)

Sabourin LA \& Rudnicki MA 2000 The molecular regulation of myogenesis. Clinical Genetics 57 16-25. (doi:10.1034/j.1399-0004.2000.570103.x)

Sayer AA, Syddall HE, Dennison EM, Gilbody HJ, Duggleby SL, Cooper C, Barker DJ \& Phillips DI 2004 Birth weight, weight at 1 y of age, and body composition in older men: findings from the Hertfordshire Cohort Study. American Journal of Clinical Nutrition 80 199-203.

Schiaffino S \& Reggiani C 2011 Fiber types in mammalian skeletal muscles. Physiological Reviews 91 1447-1531. (doi:10.1152/physrev.00031.2010)

Shen W, Mallon D, Boyle DW \& Liechty EA 2002 IGF-I and insulin regulate eIF4F formation by different mechanisms in muscle and liver in the ovine fetus. American Journal of Physiology. Endocrinology and Metabolism 283 E593-E603.

Shen W, Wisniowski P, Ahmed L, Boyle DW, Denne SC \& Liechty EA 2003 Protein anabolic effects of insulin and IGF-I in the ovine fetus. American Journal of Physiology. Endocrinology and Metabolism 284 E748-E756.

Shen WH, Boyle DW, Wisniowski P, Bade A \& Liechty EA 2005 Insulin GF-I stimulate the formation of the eukaryotic initiation factor $4 \mathrm{~F}$ complex and protein synthesis in C2C12 myotubes independent of availability of external amino acids. Journal of Endocrinology 185 275-289. (doi:10.1677/joe.1.06080)

Simoneau JA \& Bouchard C 1995 Genetic determinism of fiber type proportion in human skeletal muscle. FASEB Journal 9 1091-1095.

Singhal A, Wells J, Cole TJ, Fewtrell M \& Lucas A 2003 Programming of lean body mass: a link between birth weight, obesity, and cardiovascular disease? American Journal of Clinical Nutrition 77 726-730.

Spiller MP, Kambadur R, Jeanplong F, Thomas M, Martyn JK, Bass JJ \& Sharma M 2002 The myostatin gene is a downstream target gene of basic helix-loop-helix transcription factor MyoD. Molecular and Cellular Biology 22 7066-7082. (doi:10.1128/MCB.22.20.7066-7082. 2002)

Srikanthan P \& Karlamangla AS 2011 Relative muscle mass is inversely associated with insulin resistance and prediabetes. Findings from the third National Health and Nutrition Examination Survey. Journal of Clinical Endocrinology and Metabolism 96 2898-2903. (doi:10.1210/ jc.2011-0435)

Straus DS, Ooi GT, Orlowski CC \& Rechler MM 1991 Expression of the genes for insulin-like growth factor-I (IGF-I), IGF-II, and IGF-binding proteins- 1 and -2 in fetal rat under conditions of intrauterine growth retardation caused by maternal fasting. Endocrinology 128 518-525. (doi:10.1210/endo-128-1-518)

Suryawan A, Jeyapalan AS, Orellana RA, Wilson FA, Nguyen HV \& Davis TA 2008 Leucine stimulates protein synthesis in skeletal muscle of neonatal pigs by enhancing mTORC1 activation. American Journal of Physiology. Endocrinology and Metabolism 295 E868-E875. (doi:10.1152/ ajpendo.90314.2008)

Suryawan A, Torrazza RM, Gazzaneo MC, Orellana RA, Fiorotto ML, El-Kadi SW, Srivastava N, Nguyen HV \& Davis TA 2012 Enteral leucine supplementation increases protein synthesis in skeletal and cardiac muscles and visceral tissues of neonatal pigs through mTORC1dependent pathways. Pediatric Research 71 324-331. (doi:10.1038/ pr.2011.79)
Taguchi M, Ishikawa-Takata K, Tatsuta W, Katsuragi C, Usui C, Sakamoto S \& Higuchi M 2011 Resting energy expenditure can be assessed by fat-free mass in female athletes regardless of body size. Journal of Nutritional Science and Vitaminology 57 22-29. (doi:10.3177/jnsv.57.22)

Takahashi A, Kureishi Y, Yang J, Luo Z, Guo K, Mukhopadhyay D, Ivashchenko Y, Branellec D \& Walsh K 2002 Myogenic Akt signaling regulates blood vessel recruitment during myofiber growth. Molecular and Cellular Biology 22 4803-4814. (doi:10.1128/MCB.22.13.48034814.2002)

Tchirikov M, Rybakowski C, Huneke B \& Schroder HJ 1998 Blood flow through the ductus venosus in singleton and multifetal pregnancies and in fetuses with intrauterine growth retardation. American Journal of Obstetrics and Gynecology 178 943-949. (doi:10.1016/S00029378(98)70528-9)

Teboul L, Gaillard D, Staccini L, Inadera H, Amri EZ \& Grimaldi PA 1995 Thiazolidinediones and fatty acids convert myogenic cells into adipose-like cells. Journal of Biological Chemistry $27028183-28187$. (doi:10.1074/jbc.270.47.28183)

Ten Broek RW, Grefte S \& Von den Hoff JW 2010 Regulatory factors and cell populations involved in skeletal muscle regeneration. Journal of Cellular Physiology 224 7-16. (doi:10.1002/jcp.22127)

Thorn SR, Regnault TR, Brown LD, Rozance PJ, KengJ, Roper M, Wilkening RB, Hay WW Jr \& Friedman JE 2009 Intrauterine growth restriction increases fetal hepatic gluconeogenic capacity and reduces messenger ribonucleic acid translation initiation and nutrient sensing in fetal liver and skeletal muscle. Endocrinology 150 3021-3030. (doi:10.1210/ en.2008-1789)

Thureen PJ, Melara D, Fennessey PV \& Hay WW Jr 2003 Effect of low versus high intravenous amino acid intake on very low birth weight infants in the early neonatal period. Pediatric Research 53 24-32. (doi:10.1203/ 00006450-200301000-00008)

Tipton KD, Borsheim E, Wolf SE, Sanford AP \& Wolfe RR 2003 Acute response of net muscle protein balance reflects 24 -h balance after exercise and amino acid ingestion. American Journal of Physiology. Endocrinology and Metabolism 284 E76-E89.

Tudehope D, Vento M, Bhutta Z \& Pachi P 2013 Nutritional requirements and feeding recommendations for small for gestational age infants. Journal of Pediatrics 162 S81-S89. (doi:10.1016/j.jpeds.2012.11.057)

Tuuli MG, Cahill A, Stamilio D, Macones G \& Odibo AO 2011 Comparative efficiency of measures of early fetal growth restriction for predicting adverse perinatal outcomes. Obstetrics and Gynecology 117 1331-1340. (doi:10.1097/AOG.0b013e31821ae239)

Valdez R, Athens MA, Thompson GH, Bradshaw BS \& Stern MP 1994 Birthweight and adult health outcomes in a biethnic population in the USA. Diabetologia 37 624-631. (doi:10.1007/BF00403383)

de Vrijer B, Davidsen ML, Wilkening RB, Anthony RV \& Regnault TR 2006 Altered placental and fetal expression of IGFs and IGF-binding proteins associated with intrauterine growth restriction in fetal sheep during early and mid-pregnancy. Pediatric Research 60 507-512. (doi:10.1203/ 01.PDR.0000242364.78002.71)

Ward SS \& Stickland NC 1991 Why are slow and fast muscles differentially affected during prenatal undernutrition? Muscle \& Nerve 14 259-267. (doi:10.1002/mus.880140310)

Wank V, Bauer R, Walter B, Kluge H, Fischer MS, Blickhan R \& Zwiener U 2000 Accelerated contractile function and improved fatigue resistance of calf muscles in newborn piglets with IUGR. American Journal of Physiology. Regulatory, Integrative and Comparative Physiology 278 R304-R310.

Ward MA, Neville TL, Reed JJ, Taylor JB, Hallford DM, Soto-Navarro SA, Vonnahme KA, Redmer DA, Reynolds LP \& Caton JS 2008 Effects of selenium supply and dietary restriction on maternal and fetal metabolic hormones in pregnant ewe lambs. Journal of Animal Science 86 1254-1262. (doi:10.2527/jas.2007-0509)

Warner MJ \& Ozanne SE 2010 Mechanisms involved in the developmental programming of adulthood disease. Biochemical Journal 427 333-347. (doi:10.1042/BJ20091861)

Published by Bioscientifica Ltd. 
Waterlow JC 1984 Protein turnover with special reference to man. Quarterly Journal of Experimental Physiology 69 409-438.

Weigl LG 2012 Lost in translation: regulation of skeletal muscle protein synthesis. Current Opinion in Pharmacology 12 377-382. (doi:10.1016/ j.coph.2012.02.017)

Weinberg RA 1995 The retinoblastoma protein and cell cycle control. Cell 81 323-330. (doi:10.1016/0092-8674(95)90385-2)

Whincup PH, Kaye SJ, Owen CG, Huxley R, Cook DG, Anazawa S, Barrett-Connor E, Bhargava SK, Birgisdottir BE, Carlsson S et al. 2008 Birth weight and risk of type 2 diabetes: a systematic review. Journal of the American Medical Association 300 2886-2897. (doi:10.1001/jama. 2008.886)

White RB, Bierinx AS, Gnocchi VF \& Zammit PS 2010 Dynamics of muscle fibre growth during postnatal mouse development. BMC Developmental Biology 10 21. (doi:10.1186/1471-213X-10-21)

Widdowson EM, Crabb DE \& Milner RD 1972 Cellular development of some human organs before birth. Archives of Disease in Childhood $\mathbf{4 7}$ 652-655. (doi:10.1136/adc.47.254.652)

Wigmore PM \& Stickland NC 1983 Muscle development in large and small pig fetuses. Journal of Anatomy 137 235-245.

Wilson SJ, Ross JJ \& Harris AJ 1988 A critical period for formation of secondary myotubes defined by prenatal undernourishment in rats. Development 102 815-821.

Wolfe RR 2005 Regulation of skeletal muscle protein metabolism in catabolic states. Current Opinion in Clinical Nutrition and Metabolic Care 8 61-65. (doi:10.1097/00075197-200501000-00009)

Wolfe RR 2006 The underappreciated role of muscle in health and disease. American Journal of Clinical Nutrition 84 475-482.

Woo M, Isganaitis E, Cerletti M, Fitzpatrick C, Wagers AJ, JimenezChillaron J \& Patti ME 2011 Early life nutrition modulates muscle stem cell number: implications for muscle mass and repair. Stem Cells and Development 20 1763-1769. (doi:10.1089/scd.2010.0349)

Woods KA, Camacho-Hubner C, Savage MO \& Clark AJ 1996 Intrauterine growth retardation and postnatal growth failure associated with deletion of the insulin-like growth factor I gene. New England Journal of Medicine 335 1363-1367. (doi:10.1056/NEJM199610313351805)

Yajnik CS 2004a Obesity epidemic in India: intrauterine origins? Proceedings of the Nutrition Society 63 387-396. (doi:10.1079/ PNS2004365)
Yajnik CS $2004 b$ Early life origins of insulin resistance and type 2 diabetes in India and other Asian countries. Journal of Nutrition 134 205-210.

Yajnik CS, Fall CH, Coyaji KJ, Hirve SS, Rao S, Barker DJ, Joglekar C \& Kellingray S 2003 Neonatal anthropometry: the thin-fat Indian baby. The Pune Maternal Nutrition Study. International Journal of Obesity and Related Metabolic Disorders 27 173-180. (doi:10.1038/sj.ijo.802219)

Yang Y \& Makita T 1996 Immunocytochemical localization of desmin in human fetal skeletal muscle. Journal of Electron Microscopy 45 401-406. (doi:10.1093/oxfordjournals.jmicro.a023458)

Yau KI \& Chang MH 1993 Growth and body composition of preterm, smallfor-gestational-age infants at a postmenstrual age of 37-40 weeks. Early Human Development 33 117-131. (doi:10.1016/0378-3782(93)90207-B)

Yin H, Price F \& Rudnicki MA 2013 Satellite cells and the muscle stem cell niche. Physiological Reviews 93 23-67. (doi:10.1152/physrev. 00043.2011)

Yliharsila H, Kajantie E, Osmond C, Forsen T, Barker DJ \& Eriksson JG 2007 Birth size, adult body composition and muscle strength in later life. International Journal of Obesity 31 1392-1399. (doi:10.1038/sj.ijo. 0803612)

Zammit PS, Partridge TA \& Yablonka-Reuveni Z 2006 The skeletal muscle satellite cell: the stem cell that came in from the cold. Journal of Histochemistry and Cytochemistry 54 1177-1191. (doi:10.1369/jhc. 6R6995.2006)

Zhao J, Brault JJ, Schild A, Cao P, Sandri M, Schiaffino S, Lecker SH \& Goldberg AL 2007 FoxO3 coordinately activates protein degradation by the autophagic/lysosomal and proteasomal pathways in atrophying muscle cells. Cell Metabolism 6 472-483. (doi:10.1016/j.cmet. 2007.11.004)

Zhu MJ, Ford SP, Nathanielsz PW \& Du M 2004 Effect of maternal nutrient restriction in sheep on the development of fetal skeletal muscle. Biology of Reproduction 71 1968-1973. (doi:10.1095/biolreprod.104.034561)

Zhu MJ, Ford SP, Means WJ, Hess BW, Nathanielsz PW \& Du M 2006 Maternal nutrient restriction affects properties of skeletal muscle in offspring. Journal of Physiology 575 241-250. (doi:10.1113/jphysiol. 2006.112110)

Ziebell BT, Galan HL, Anthony RV, Regnault TR, Parker TA \& Arroyo JA 2007 Ontogeny of endothelial nitric oxide synthase mRNA in an ovine model of fetal and placental growth restriction. American Journal of Obstetrics and Gynecology 197 420-425. (doi:10.1016/j.ajog. 2007.07.016)

Received in final form 5 February 2014

Accepted 13 February 2014

Accepted Preprint published online 14 February 2014 http://joe.endocrinology-journals.org DOI: 10.1530/JOE-13-0567
(C) 2014 Society for Endocrinology Printed in Great Britain 